\title{
Modified Hypoxia Inducible Factor expression in CD8+ T cells increases anti-tumor efficacy
}

Pedro Veliça ${ }^{1}$, Pedro Pacheco Cunha ${ }^{1,2}$, Nikola Vojnovic ${ }^{1}$, losifina Petrina Foskolou ${ }^{1,2}$, David Bargiela ${ }^{1,2}$, Milos Gojkovic ${ }^{1}$, Helene Rundqvist ${ }^{3}$, Randall Scott Johnson ${ }^{1,2}$

1 Department of Cell and Molecular Biology, Karolinska Institutet, Sweden

2 Department of Physiology, Development and Neuroscience, University of Cambridge, Cambridge, UK

${ }^{3}$ Department of Laboratory Medicine, Karolinska Institutet, Sweden

Corresponding author: Prof. Randall S Johnson

Department of Cell and Molecular Biology (CMB), Biomedicum (5C), Solnavägen 9, 17165 Solna, Sweden. Telephone: +46852487938. Email: randall.johnson@ki.se

The authors have declared that no conflict of interest exists.

Running title: Modified HIF expression in CD8+ T cells increases anti-tumor efficacy

Keywords: hypoxia, CD8+ T cells, adoptive cell transfer, immunotherapy, CAR

Funding has been provided by the Swedish Cancer Society (Cancerfonden), the Swedish Childhood Cancer Fund (Barncancerfonden), and the Swedish Research Council (Vetenskapsrådet)
Abstract:
224 words
Text:
5269 words
Figures:
Supplementary Figures: 5 


\section{Abstract}

Adoptive transfer of anti-tumor cytotoxic $\mathrm{T}$ cells is a novel form of cancer immunotherapy, and a key challenge is to ensure the survival and function of the transferred T cells. Immune cell survival requires adaptation to different microenvironments, and particularly to the hypoxic milieu of solid tumors. The HIF transcription factors are an essential aspect of this adaptation, and we undertook experiments to define structural determinants of HIF that would potentiate anti-tumor efficacy in cytotoxic T cells. We created retroviral vectors to deliver ectopic expression of HIF-1a and HIF-2a in mouse CD8+ T cells, together or individually, and with or without sensitivity to their oxygen-dependent inhibitors Von Hippel-Lindau (VHL) and Factor Inhibiting HIF (FIH). We found that HIF-2a, but not HIF-1a, drives broad transcriptional changes in CD8+ T cells, resulting in increased cytotoxic differentiation and cytolytic function against tumor targets. We further found that a specific mutation replacing the hydroxyl group acceptor site for $\mathrm{FIH}$ in the HIF-2a isoform gives rise to the most effective anti-tumor T cells after adoptive transfer in vivo. Lastly, we show that co-delivering an FIH-insensitive form of HIF-2a with an anti-CD19 chimeric antigen receptor greatly enhances cytolytic function of human CD8+ T cells against lymphoma cells. These experiments provide a means to increase the anti-tumor efficacy of therapeutic CD8+ T cells via ectopic expression of the HIF transcription factor. 
bioRxiv preprint doi: https://doi.org/10.1101/2020.06.18.159137; this version posted July 2, 2020. The copyright holder for this preprint (which was not certified by peer review) is the author/funder, who has granted bioRxiv a license to display the preprint in perpetuity. It is made available under aCC-BY-NC-ND 4.0 International license.

\section{Graphical abstract}
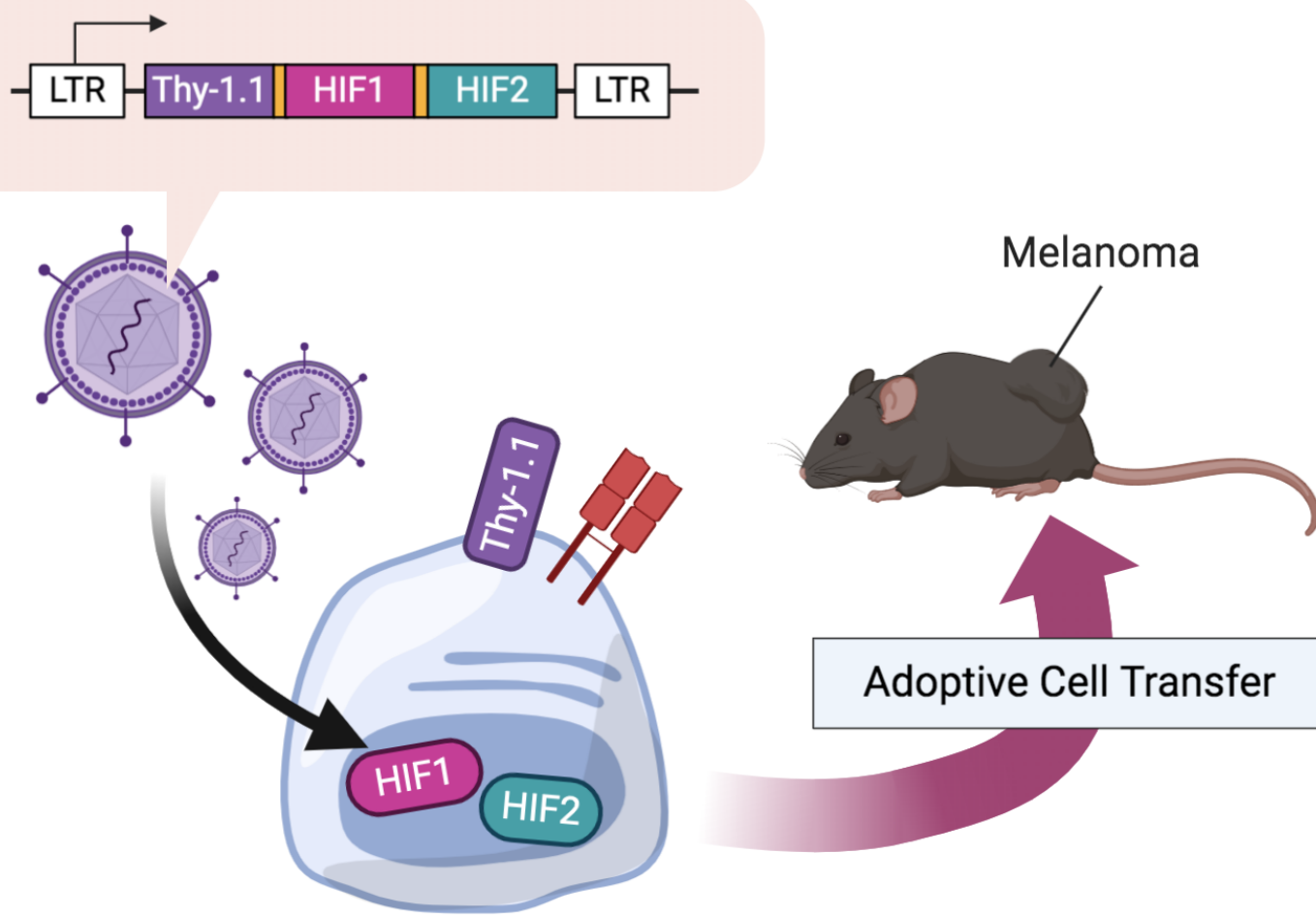

Cytotoxic T cell 


\section{Introduction}

2 CD8+ $T$ cells are the cytotoxic arm of the adaptive immune system and play an

3 essential role in anti-tumor immunity. One key immunotherapeutic strategy is the

4 redirection of $\mathrm{T}$ cells against tumor antigens by retroviral gene transfer of defined T-

5 cell receptors (TCR), or chimeric antigen receptors (CAR), which can be adoptively

6 transferred into cancer patients, and mediate tumor regression in some forms of

7 malignancies (1-3).

8 The manufacturing process of TCR/CAR T cells can be used to perform additional

9 genetic interventions in order to improve safety and anti-tumor efficacy of the T-cell

10 product. Such interventions include CRISPR-mediated disruption of the endogenous

11 TCR loci (4), disruption of the inhibitor checkpoint protein PD-1 (5) or co-delivery of

12 genes for cytokines (6), chemokines or their receptors $(7,8)$, as well as suicide genes

13 (9). Transcription factors are able to exert large phenotypic changes and guide T-cell

14 differentiation (10) making them an appealing target in TCR/CAR T-cell

15 immunotherapy.

16 The hypoxia-inducible transcription factors (HIF) are primary regulators of the

17 transcriptional response to hypoxia $(11,12)$. HIFs function as heterodimers composed

18 of an alpha (HIF-1 $\alpha$ or HIF-2 $\alpha$ ) and a beta subunit (ARNT/HIF-1 $\beta$ ) and their function is

19 efficiently inhibited by oxygen. In the presence of oxygen, HIF-a subunits are

20 hydroxylated at two conserved prolines by prolyl-hydroxylases (PHD), leading to

21 recognition and ubiquitination by the Von Hippel-Lindau (VHL) protein and resulting in

22 proteasomal degradation $(13,14)$. The second oxygen-sensitive mechanism utilizes

23 the Factor Inhibiting HIF (FIH) enzyme, which hydroxylates a conserved asparagine

24 residue in HIF- $\alpha$ subunits, blocking association with the p300/CBP coactivator and 
thus HIF transcriptional activity $(15,16)$. These repressive mechanisms are reduced or eliminated in low-oxygen environments leading to HIF stabilization, translocation to

27 the nucleus and induction of a hypoxia-response gene expression program.

Low oxygen availability in tumors and in inflamed tissues has historically been characterized as immunosuppressive (17-19) but a number of recent studies have shown that CD8+ $T$ cells differentiate more efficiently into cytotoxic $T$ cells when cultured in low oxygen $(20,21)$, suggesting that T-cell differentiation is functionally linked to decreased oxygen availability.

This hypothesis was further supported by genetic deletion of VHL (21) or the three PHD isoforms (22) which caused constitutive accumulation of HIF-1 $\alpha$ and HIF-2 $\alpha$ in T cells and increased cytotoxic differentiation as well as improved rejection of primary and metastatic tumors. Ablation of HIF activity via deletion of ARNT (23) or HIF-1a (24) had the opposite effect, resulting in poorer cytotoxic differentiation, and reduced tumor rejection after adoptive transfer.

Based on these studies, we hypothesized that engineering CD8+ T cells to enhance HIF expression would result in T cells with enhanced anti-tumor properties. To test this hypothesis, we designed retroviral vectors to ectopically express HIF-1 $\alpha$ and HIF-2 $\alpha$, alone or in combination, and with or without susceptibility to oxygen-dependent regulation by either VHL- or FIH-dependent mechanisms. We screened these HIF

44 variants in CD8+ T cells to determine whether they enhance in vivo anti-tumor efficacy.

45 Our results demonstrate the potential for use of engineered HIF activity as a means to boost $\mathrm{T}$ cell function in adoptive $\mathrm{T}$ cell immunotherapy. 


\section{Materials and Methods}

\section{Animals}

49 C57BL/6J (CD45.2) animals were purchased from Janvier Labs. Donor TCRtransgenic OT-I mice (catalogue 003831, The Jackson Laboratory) were crossed with

51 mice bearing the CD45.1 congenic marker (catalogue 002014, The Jackson 52 Laboratory) or TdTomato dLck Cre reporter mice (catalogue 007914 and 012837 , The 53 Jackson Laboratory).

\section{$54 \quad$ Cell lines}

HEK293 was a gift from Prof. Dantuma (Karolinska Institute, Stockholm). EL4 was a gift from Prof. H. Stauss (UCL, London). B16-F10 and LLC were purchased from ATCC (CRL-6475 and CRL-1642, respectively). B-luciferase-GFP Raji (B-HCL-010) and B-luciferase K562 (B-HCL-013).

\section{Vectors}

DNA encoding a codon-optimized polycistronic peptide composed of mouse Thy-1.1

61 (AAR17087.1), mouse HIF-1a (NP_034561.2; P402A, P577A, N813A) and mouse HIF-2a (NP_034267.3; P404A, P530A, N851A) interspersed with picornavirus P2A

63 (GSGATNFSLLKQAGDVEENPGP) and furin (RAKR) cleavage sequences was synthesized by Gene Art (Thermo Fisher). Cell surface and nuclear localization peptides were incorporated into the Thy-1.1 and HIF sequences, respectively. Quick Change II Site-directed mutagenesis (Agilent) was used to revert mutated sites to the

67 native sequence. DNA encoding a codon-optimized polycistronic peptide composed of eGFP (ADQ43426.1), anti-human CD19 CAR and human HIF-2a (NP_001421.2, 
N847A) interspersed with picornavirus $\mathrm{P} 2 \mathrm{~A}$ and furin cleavage sequences was synthesized by Gene Art (Thermo Fisher). The coding sequences were cloned into the

71 gamma retroviral vector pMP71, a gift from Christopher Baum (MHH, Hannover). DNA encoding a codon-optimized polycistronic peptide composed of chicken ovalbumin (OVA; P01012.2), eGFP (ADQ43426.1) and neomycin phosphotransferase (NeoR; CAD21956.1) interspersed with P2A and furin cleavage sites was synthesized by Gene Art (Thermo Fisher) and cloned under control of the SV40 promoter in the transposon vector pT2/BH, a gift from Perry Hackett (Addgene plasmid \#26556). pCMV-SB11 encoding the sleeping beauty transposase was a gift from Perry Hackett (Addgene plasmid \#26552).

\section{CD8+ T-cell sourcing, activation and restimulation}

CD8+ $T$ cells from female and male mice were purified from spleens by CD8a positive selection magnetic bead sorting (Miltenyi) and activated in complete RPMI (Thermo Fisher) supplemented with $55 \mu \mathrm{M}$ 2-ME (Thermo Fisher) with $2 \mu \mathrm{g} / \mathrm{ml}$ ConA (Sigma) and $10 \mathrm{ng} / \mathrm{ml}$ recombinant human IL-7 (R\&D Systems) for 24 hours before transduction. Whole OT-I splenocytes were activated with $100 \mathrm{ng} / \mathrm{ml}$ SIINFEKL (Prolmmune) 24 hours before transduction. Transduced CD8+ $\mathrm{T}$ cells were restimulated with anti-mouse CD3/CD28 dynabeads (Thermo Fisher) at a 1:1 cell-tobead ratio or $100 \mathrm{ng} / \mathrm{ml}$ SIINFEKL. Transduced CD8+ T cells were expanded in the presence of $10 \mathrm{U} / \mathrm{ml}$ recombinant human IL-2 (Sigma) Human CD8+ T cells were purified from donor PBMCs (Cambridge Bioscience or NHSBT) by negative selection magnetic bead sorting (Miltenyi) and activated in complete RPMI supplemented with bead ratio. 


\section{Retroviral transductions}

94 Sub-confluent HEK293 cultures were transfected with HIF-encoding vectors and

95 helper vector pCL-Eco, a gift from Inder Verma (Addgene plasmid \#12371) or pCL-

Ampho (Novus). Supernatant media containing retroviral particles was harvested 48

hours after transfection and used fresh or stored at $-80^{\circ} \mathrm{C}$. Retroviral supernatants

were spun onto Retronectin-coated wells (Takara) at $2000 \mathrm{xg}$ for 2 hours at $32^{\circ} \mathrm{C}$ and

replaced with activated polyclonal, OT-I, or human CD8+ T cells in fresh RPMI

100

supplemented with 10 or $30 \mathrm{U} / \mathrm{ml}$ IL-2. Fresh media was added every 2-3 days. For

101

long-term expansion, transduced cells were re-stimulated weekly with anti-CD3/CD28

102 dynabeads.

103

104

105

106

107

108

109

110

111

112

113

114

115

116

\section{Flow cytometry.}

Single cell suspensions were stained with Near-IR Dead Cell Stain Kit (Thermo Fisher) followed by surface, cytoplasmic and/or nuclear staining with the following fluorochrome-labeled monoclonal antibodies: CD45.2 (104), CD3 (145-2C11), 4-1BB (1AH2), CD8a (53-6.7), CD8a (SK1), CD19 (HIB19), CD45RO (UCHL1), CCR7 (3D12), CD45.1 (A20), Va2 TCR (B20.1), Caspase-3 (active form) (C92-605), LAG3 (C9B7W), CD44 (IM7), PD-1 (J43), IL-2 (JES6-5H4), CD62L (MEL-14), PD-L1 (MIH5), NK-1.1 (PK136), CD147/Basigin (RL73), TCF-1 (S33-966), CTLA-4 (UC10-4F10-11), and IFN-Y (XMG1.2) purchased from BD Biosciences; CD28 (37.51), Fc Block (93), CD45.2 (104), CD80 (16-10A1), NKG2A (16A11), CD3 (17A2), H-2Kb+SIINFEKL (25D1.16), CD8 (53-6.7), CD122 (5H4), CD45.1 (A20), CD127 (A7R.34), TIM-3 (B8.2C12), ICOS (C398.4A), NKG2D (CX5), CD4 (GK1.5), TCR $\beta$ chain (H57-597), CD44 (IM7), CD184 (CXCR4) (L276F12), CD27 (LG.3A10), CD62L (MEL-14), OX40 (OX-86), Granzyme B (QA16A02), Perforin (S16009A), Granzyme C (SFC1D8), and 
117 IFN-Y (XMG1.2) purchased from BioLegend; 4-1BB (17B5), CD127 (A7R.34), Eomes

118 (Dan11mag), T-bet (eBio4B10), Thy-1.1 (CD90.1) (HIS51), CD44 (IM7), Vß5.1/5.2

119 TCR (MR9-4), CD25 (PC61.5), CD4 (RM4-5) purchased from eBioscience and

120 Granzyme B (GB12) purchased from Life Technologies. Staining of cytoplasmic and 121 nuclear antigens was performed using the Fixation/Permeabilization kit (BD

122 Biosciences) and the Transcription Factor buffer set (BD Biosciences), respectively.

123 To measure IFN $\gamma$ secretion cells were incubated overnight in complete RPMI 124 supplemented with $100 \mathrm{ng} / \mathrm{ml}$ SIINFEKL with and treated with Golgi Stop (BD 125 Biosciences) 4 hours before intracellular staining and flow cytometry analysis. For 126 proliferation assays, cells were loaded with CellTrace Violet (Thermo Fisher) 127 according to manufacturer's instructions. Samples were analyzed in a FACSCanto II 128 flow cytometer (BD Biosciences).

\section{RNA sequencing}

130 OT-I cells were expanded for 5 days in the presence of IL-2 after transduction and 131 sorted on Thy-1.1 surface expression on a BD FACSAria Fusion cell sorter (BD 132 Biosciences) directly into RLT Plus lysis buffer (Qiagen). Total RNA was subjected to 133 quality control with Agilent Tapestation according to the manufacturer's instructions.

134 To construct libraries suitable for Illumina sequencing the Illumina TruSeq Stranded 135 mRNA Sample preparation protocol which includes cDNA synthesis, ligation of 136 adapters and amplification of indexed libraries was used. The yield and quality of the 137 amplified libraries were analysed using Qubit by Thermo Fisher and the Agilent 138 Tapestation. The indexed cDNA libraries were normalised and combined and the 139 pools were sequenced on the Nextseq 550 for a 50 -cycle v2.5 sequencing run 140 generating 75 bp single-end reads. Basecalling and demultiplexing was performed 
141 using CASAVA software with default settings generating Fastq files for further

142 downstream mapping and analysis.

\section{Western blotting}

144 Nuclear protein extracts $(15-20 \mu g)$ from HEK293 cells transfected with HIF-encoding

145 vectors or from Thy-1.1-purified CD8+ T cells transduced with HIF-encoding vectors 146 were probed with polyclonal antibodies against HIF-1a (NB-100-449 or NB-100-105

147 Novus Biologicals), HIF-2a (AF2997, R\&D Systems), Lamin B (sc-6217, Santa Cruz), 148 and Histone 3 (4499S, CST) and detected using infra-red labeled secondary 149 antibodies in an Odyssey imaging system (LI-COR).

\section{Generation of OVA-expressing cell lines.}

151 B16-F10, LLC and EL4 were co-transfected with the transposon vector pT2 encoding 152 OVA, eGFP and neomycin phosphotransferase and the vector encoding transposase 153 SB11. Three days later $400 \mathrm{mg} / \mathrm{ml}$ G418 (Gibco) was added to culture media to select 154 for transgene-expressing cells. Successful integration was confirmed by analyzing 155 eGFP fluorescence by flow cytometry. Limiting dilution was used to derive monoclonal 156 OVA-expressing lines for each cell line. OVA presentation was confirmed by flow 157 cytometry using a PE-labeled antibody against surface SIINFEKL bound to H-2Kb 158 (clone 25-D1.16, BioLegend).

\section{In vitro cytotoxicity assay.}

160 OVA-expressing GFP-positive LLC or EL4 were mixed with their respective parent cell 161 line in a 1:1 ratio. Transduced OT-I cells were enriched by magnetic bead sorting against Thy-1.1 (Miltenyi) and added to the tumor cells to a final T cell to OVA-positive target ratio of 1:1. Cytotoxicity was assessed by flow cytometry 20 hours later. The 
ratio of GFP-positive events (target) to GFP-negative tumor cell events (reference) in each test co-culture was divided by the ratio from cultures without OT-I cells to calculate specific cytotoxicity. For, B16-F10-OVA 5000 cells were plated per well in flat-bottom 96 well plates and left to adhere for 1 hour before adding 1000 Thy-1.1+

$168 \mathrm{CD} 8+\mathrm{T}$ cells to a final E/T ratio of 1:5. After 20 hours co-culture wells were washed 3 169 times with PBS to remove $\mathrm{T}$ cells and the number of remaining target cells was determined by culturing with $10 \mu \mathrm{g} / \mathrm{ml}$ resazurin (Sigma) and measuring fluorescence

171 signal in a plate reader. Cytotoxicity was calculated relative to wells with no T cells 172 added. To determine cytotoxicity of CAR-transduced human $T$ cells, Raji

173 (GFP+CD19+, target) and K562 (reference) were mixed at 1:1 ratio and co-cultured 174 with varying ratios of GFP+CD8+ T cells. After 20h co-culture cytotoxicity was assessed by flow cytometry and the ratio of target to reference cells used to calculate cytotoxicity. For each donor, cytotoxicity was normalised to the VC level to determine

177 specific cytotoxicity.

\section{In vivo tumor challenge.}

1798 to 12-weeks old female C57BL/6j were inoculated subcutaneously with $5 \times 10^{5}$ B16180 F10-OVA and conditioned 4 days later with peritoneal injection of $300 \mathrm{mg} / \mathrm{kg}$ 181 cyclophosphamide (Sigma). On day 8, 0.5-1×106 Thy-1.1-purified transduced OT-I 182 CD8+ T cells were peritoneally injected. Animals were assigned randomly to each 183 experimental group. Tumor volume was measured every 2-3 days with electronic 184 calipers until day 60. Peripheral blood was collected from the tail vein at day 15 and analyzed by flow cytometry. Tumor volume was calculated using the formula $\frac{a \times b \times b}{2}$ where $a$ is the length and $b$ is the width of the tumor. 


\section{Tumor-infiltration assessment}

1888 to 12 -weeks old female C57BL/6j were inoculated subcutaneously with $5 \times 10^{5}$ B16-

189 F10-OVA and conditioned 11 days later with peritoneal injection of $300 \mathrm{mg} / \mathrm{kg}$

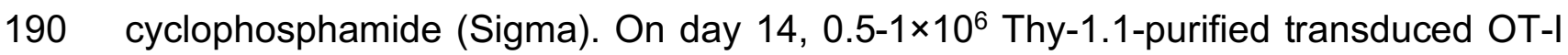

191 CD8+ T cells were peritoneally injected. Animals were assigned randomly to each 192 experimental group. On day 19, tumors were dissected, digested with $1 \mathrm{mg} / \mathrm{ml}$

193 Collagenase Type IV (Life Technologies) and $20 \mathrm{U} / \mathrm{ml}$ DNAse I (Sigma), and 194 processed in a GentleMACS dissociator (Miltenyi). The tumor single cell suspensions 195 were stained with fluorochrome-labeled antibodies and analysed by flow cytometry.

\section{Statistics}

197 Statistical analyses were performed with Prism 8 software (GraphPad). Statistical tests 198 used are stated in figure legends. Statistical significance was set at $p<0.01$ and 199 denoted in figures as $\alpha$.

\section{Study approval}

201 All animal experiments were approved by the regional animal ethics Committee of 202 Northern Stockholm, Sweden. 
204 Generation of retroviral vectors for ectopic expression of HIF-1a and HIF-2a in 205 CD8+ T cells.

206 In order to test whether ectopic expression of HIFs can increase the anti-tumor function 207 of cytotoxic CD8+ T cells we generated retroviral vectors encoding murine HIF-1a and 208 HIF-2a. HIF protein stability and transcriptional activity is regulated by oxygen at the 209 post-translational level (Figure 1A). In the presence of oxygen, prolyl hydroxylases 210 (PHD) hydroxylate conserved proline residues, leading to recognition and 211 ubiquitination by the VHL protein, thus targeting HIFs for proteasomal degradation. 212 FIH hydroxylates a conserved asparagine, which blocks recruitment of the coactivator 213 p300/CBP and impairs HIF transcriptional activity. In order to address the role of HIF 214 regulation we employed site-directed mutagenesis (Figure 1B) to convert conserved

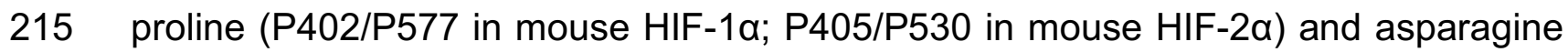
216 (N813 in mouse HIF-1 $\alpha$ and N851 in mouse HIF-2 $\alpha$ ) residues into alanine residues. 217 These alanine residues in the resultant vectors cannot be hydroxylated, and thus 218 prevent proline or asparagine hydroxylation and inhibition of HIF accumulation or 219 activity.

220 The retroviral vectors designed to carry out these experiments encode a polycistronic 221 peptide composed of Thy-1.1 (transduction marker), HIF-1a, and/or HIF-2a (Figure 222 1C). These elements are interspersed with furin and self-cleaving picornavirus $2 \mathrm{~A}$ sites 223 that enable post-translational separation of Thy-1.1 and HIF proteins. Subcellular 224 localization signal peptides traffic Thy-1.1 to the cell surface, and HIFs to the nucleus. 225 The polycistronic nature of the constructs ensures equimolar production of all proteins, 
226 while retroviral vector integration in the T-cell genome ensures constitutive and

227 heritable transgene expression.

228 A library of vectors was generated encoding either both HIF-1a and HIF-2a together, 229 or HIF-1a alone, or HIF-2a alone, and in every mutational arrangement; these are 230 denoted henceforth as PPN (hydroxylated by VHL and FIH), PPA (hydroxylated by 231 VHL only), AAN (hydroxylated by FIH only), and AAA (no hydroxylation by either VHL or FIH). An empty vector control (VC) was generated that encodes Thy-1.1 alone. The 233 ability of these vectors to deliver HIF-1a and HIF-2a protein expression was confirmed 234 in nuclear extracts of transfected HEK cells (Figure 1D). Ectopic expression of HIF 235 isoforms was achieved with every mutational combination. As expected, mutation of 236 proline residues resulted in increased HIF protein accumulation due to the absence of 237 VHL-driven proteasomal degradation.

238 During retroviral transduction primary mouse CD8+ T cells are activated 24 hours 239 before transduction with retroviral particles, and expanded for a further 3 to 5 days in 240 the presence of IL-2 (Figure 1E). Transduced cells expressing Thy-1.1 on the cell 241 surface can be identified and characterized by flow cytometry (Figure 1F) or purified using magnetic bead sorting for subsequent analysis. Ectopic expression of HIF-1a

243 and HIF-2a was confirmed in nuclear extracts of transduced CD8+ T cells (Figure 1G).

244 Having validated these vectors we next proceeded to investigate the effect of ectopic 245 HIF expression on CD8+ T-cell gene expression, effector differentiation, and anti246 tumor function.

\section{Ectopic HIF-2a expression dramatically alters the CD8+ T-cell transcriptome.}

248 To assess the impact of ectopic HIF expression on global gene expression we 249 performed transcriptomic analyses of CD8+ T cells transduced with either HIF-1a or 250 HIF-2a. To increase homogeneity in these analyses we transduced CD8+ T cells from 
the transgenic OT-I mouse strain in which all T cells express the same MHC class Irestricted TCR specific against a fragment of chicken ovalbumin (OVA) (Figure 2A). Five days after transduction, Thy $-1.1^{+}$OT-I cells were sorted by flow cytometry for 254 RNA purification followed by RNA sequencing (RNA-seq). In total, 12155 individual 255 transcripts were detected and mapped (Figure 2B). Average transcript frequency and 256 rank distribution was similar to previously published transcriptomic analyses of CD8+ 257 T cells $(25,26)$ including high levels of expression of genes defining CD8+ T-cell identity such as Gzmb, Cd8a, Cd3g, Prf1 and Ifng.

We next compared transcript frequency of HIF-transduced CD8+ T cells with vector control (VC)-transduced CD8+ T cells (Figure 2C). Ectopic expression of VHLsensitive (PPN and PPA) HIF-1a had minimal impact on gene expression, with only 5 and 11 differentially expressed genes, respectively (Figure 2D). Ablation of VHL

transcriptional changes in this context. Indeed, we were only able to detect nuclear HIF-1a protein in extracts from CD8+ T cells if VHL regulation was absent (AAN and AAA) (Figure 1G).

Ectopic expression of HIF-2a resulted in a significantly greater number of differentially expressed genes relative to expression of HIF-1a, irrespective of regulatory status 270 (Figure 2C, 2D). HIF-2a altered the expression of 1300, 743, 1491 and 2353 genes in 271 the PPN, PPA, AAN and AAA formats, respectively. Furthermore, the magnitude of changes in gene expression was generally higher in HIF-2a-expressing CD8+ T cells 273 than in those expressing HIF-1a (Figure 2E).

274 There was high transcriptional similarity amongst cells expressing ectopic HIF-1a, 275 irrespective of susceptibility to $\mathrm{VHL}$ or FIH inhibition (Figure 2F). The transcriptional 
changes elicited by HIF-2a were also similar amongst the PPN, PPA, AAN and AAA variants. However, HIF-1a and HIF-2a appear to alter CD8+ T-cell transcription differently, as shown by low correlation coefficients when comparing differentially expressed genes between the two HIF isoform mutational groups (Figure 2F).

280 Ectopic HIF-2a altered the expression of several genes involved in CD8+ T-cell 281 function (Figure 3A). Notably, HIF-2a increased expression of perforin (Prf1) and granzyme B (Gzmb), two highly expressed proteins essential for cytolytic function.

283 Ectopic HIF-2a also increased expression of co-stimulators such as CD30 (Tnfrsf8), 4-1BB (Tnfrsf9), OX40 (Tnfrsf4) and ICOS (Icos) and the co-inhibitors LAG3 (Lag3) and CTLA-4 (Ctla4). Reduced expression of interferon-gamma (Ifng), a cytokine that promotes anti-tumor function by inducing antigen presentation in cancer cells, as well as its receptor (Ifngr1 and Ifngr2) was detected in HIF-2a-expressing cells. Expression of the alpha (CD25; II2ra) and beta chains (CD122; II2rb) of the IL-2 receptor was increased, suggesting a greater responsiveness to IL-2. Genes involved in T-cell trafficking such as integrins and the bone marrow-homing receptor CXCR4 (Cxcr4) (27) were also induced by ectopic HIF-2a expression.

292 The broad transcriptional changes induced by HIF-2a can be partially explained by altered expression of a wide array of transcriptional factors and transcriptional modulators (Supplementary Figure 1 A and B). While few transcriptional modulators were altered by HIF-1a, ectopic expression of HIF-2a significantly altered expression of $77,40,98$, and 135 transcriptional modulator genes in the PPN, PPA, AAN and AAA mutational variants respectively, thus amplifying the transcriptional impact of HIF-2a.

298 Notably, HIF-2a decreased expression of transcription factors associated with naive/memory as well as the exhausted state (Tcf7 $(28,29)$, Tox $(30), \mathrm{Nr} 4 a 1, \mathrm{Nr} 4 a 3$ 300 (31) and Eomes (32)). Transcripts associated with a response to hypoxia 
301 (Supplementary Figure 1C) and induction of glycolysis (Supplementary Figure 1D)

302 were also upregulated in CD8+ T cells expressing HIF-2a, but not in those expressing 303 HIF-1a.

304 HIF-2a drives phenotypical changes in CD8+ T cells, particularly in the absence of VHL suppression.

306 We next sought to confirm if the transcriptional changes induced by ectopic HIF expression translated to alterations in protein expression. For that we transduced CD8+ T cells with vectors encoding HIF-1a and HIF-2a together, HIF-1a alone, or HIF$2 \mathrm{a}$ alone and analysed their phenotype by flow cytometry (Figure 3B). In line with the 310 RNA-seq results described above, expression of the co-inhibitors LAG3 and CTLA-4 311 was augmented by HIF-2a, particularly in the absence of VHL inhibition (AAN and 312 AAA). Ectopic co-expression of HIF-1a and HIF-2a yielded similar results to HIF-2a alone. Increased expression of the IL-2 receptor chains CD25 (Figure 3B) and CD122

314 (Supplementary Figure 2A) was also confirmed at the protein level as was expression 315 of the chemokine receptor CXCR4 (Supplementary Figure 2A). Likewise, expression 316 of GZMB, ICOS and 4-1BB, key components of the cytotoxic function of CD8+ T cells, 317 was increased by ectopic expression of HIF-2a (Figure 3B). Notably, GZMB expression was only significantly increased when HIF-2a was susceptible to VHL regulation (PPN and PPA). Suppression of the transcription factor EOMES by HIF-2a was also confirmed by intranuclear flow cytometry. Of the assayed proteins only 321 CD147 (Basigin), a known direct HIF-1a target (33), was augmented by HIF-1a (Figure 3B). The increased expression of GZMB, LAG3, CTLA-4, CD25 and 4-1BB and suppression of EOMES was confirmed in CD8+ T cells transduced with HIF-2a and 324 cultured over a period of 21 days with weekly restimulation (Supplementary Figure 2B 325 and C), confirming the long-term stability of the phenotypes conferred by the integrated 
retroviral vectors. Altogether, these data show that ectopic HIF-2a expression, but not HIF-1a, was able to substantially alter the phenotype of CD8+ T cells and that the magnitude of those changes is greater in the absence of inhibition by VHL.

\section{Ectopic expression of VHL-insensitive HIF-2a reduces cell proliferation, TCR}

\section{expression and IFNy secretion while VHL-sensitive HIF-2a enhances CD8+ T-}

cell cytotoxicity against cancer cells.

During long-term culture of HIF-transduced CD8+ T cells (Supplementary Figure 2B)

the frequency of cells expressing VHL-insensitive HIF-2a (AAN and AAA) diminished

334 progressively over time (Figure 4A) unlike the remaining transduced populations

335 whose frequency in culture increased slightly over 21 days. This was due to reduced 336 proliferation of VHL-insensitive HIF-2a-transduced CD8+ T cells (Figure 4B, 4C and 337 Supplementary Figure 3A) and not due to increased apoptosis (Supplementary Figure 338 3B).

339 Transcriptomic analysis revealed downregulation of genes encoding TCR chains in 340 HIF-2a-transduced cells, particularly when VHL regulation was absent (Figure 4D).

341 OT-I cells transduced with VHL-insensitive (AAN and AAA) HIF-2a had reduced surface expression of TCR alpha (Va2) and TCR beta (Vß5) chains (Figure 4E), while

343 VHL-sensitive HIF-2a or any form of HIF-1a had no effect on TCR expression. Loss of 344 TCR chains occurred synchronously resulting in TCR loss in over $50 \%$ of AAN and 345 AAA HIF-2a-expressing cells (Figure 4F and 4G) TCR loss occurred progressively 346 after transduction (Supplementary Figure 3C) and was also observed in polyclonal 347 CD8+ T cells expressing these vectors (Figure 4H).

348 Production of IFNy after TCR triggering with OVA was also reduced in OT-I cells 349 transduced with VHL-insensitive HIF-2a (AAN and AAA) (Figure 5A and 5B), a likely 350 consequence of reduced TCR expression, since stimulation with PMA and ionomycin, 
which bypasses the TCR, resulted in unchanged IFNy secretion (Supplementary

352 Figure 2C).

353 To assess how the phenotypic and functional changes caused by ectopic HIF-2a 354 expression affect cytotoxicity against tumor cells, we co-cultured transduced OT-I cells 355 with OVA-expressing EL4 thymoma, Lewis Lung Carcinoma (LLC) or B16-F10 356 melanoma cancer cells (Figure 5C). Ectopic HIF-2a expression increased cytotoxicity 357 against EL4, LLC and B16-F10 cells, but only if sensitivity to VHL was retained (PPN and PPA). Expression of VHL-insensitive HIF-2a (AAN and AAA) had no effect on cytotoxicity. Killing of B16-F10 cells was similar whether co-culture occurred at 360 atmospheric oxygen conditions $\left(21 \% \mathrm{O}_{2}\right)$ or at physiologically relevant oxygen 361 tensions $\left(5 \%\right.$ and $\left.1 \% \mathrm{O}_{2}\right)$. This result can be partly attributed to increased GZMB levels 362 (Figure 3B) and to largely unchanged proliferation rates, TCR expression and IFNy secretion in the HIF-2a PPN and PPA groups (Figures 4 and 5). Overall, these results reveal that ectopic expression of highly stable HIF-2a protein (AAN and AAA) in CD8+ T cells leads to a deleterious phenotype while expression VHL-sensitive (PPN and PPA) HIF-2a potentiates in vitro cytotoxicity against tumor cells. results in delayed tumor growth and increased survival rate.

In therapy, adoptively transferred CAR/TCR engineered $\mathrm{T}$ cells must engraft, 370 proliferate, traffic to tumor sites and eliminate cancer cells in order to deliver 371 therapeutic benefit. To test the anti-tumor function of HIF-transduced CD8+ T cells we employed a mouse model of adoptive cell therapy (ACT) (Figure 6A). Wild-type mice 373 were inoculated with OVA-expressing B16-F10 melanoma cells, followed by 374 lymphodepleting chemotherapy and adoptive transfer of HIF-1a- or HIF-2a-transduced 375 OT-I cells (Supplementary Figure 4A). A week after T-cell injection, peripheral blood 
was harvested, and the frequency of transduced OT-I cells assessed by flow cytometry

377 (Figure 6B and Supplementary Figure 4B). The engraftment of T cells expressing VHLand FIH-sensitive (PPN) HIF-2a was significantly increased, while cells expressing VHL-insensitive (AAN and AAA) HIF-2a were nearly absent in peripheral blood. The

380 frequency of $\mathrm{T}$ cells expressing $\mathrm{VHL}$ - and $\mathrm{FIH}$-insensitive (AAA) HIF-1a was also 381 reduced relative to the control group.

382 In this model, transfer of VC-transduced OT-I CD8+ T cells delayed tumor growth relative to the untreated (no ACT) group, and increased median survival from 22 to 29 days. However, there were no complete regressions in this group (Figure 6D and 385 Supplementary Figure 4C). Adoptive transfer of T cells expressing VHL-sensitive, but 386 FIH-insensitive (PPA) HIF-2a both significantly delayed tumor growth while boosting median survival to 34 days, and fully eliminated tumors in $23 \%$ of the treated animals (Figure 6D and Supplementary Figure 4C). In contrast, animals receiving $\mathrm{T}$ cells expressing VHL-insensitive but FIH-sensitive (AAN) HIF-2a performed significantly worse than controls, resulting in median survival times comparable to those of the untreated group (23 days). Likewise, T cells expressing VHL- and FIH-insensitive (AAA) HIF-1a failed to protect animals from tumor growth, while the FIH-insensitive (PPA) HIF-1a variant resulted in complete tumor clearance in $15 \%$ of animals; albeit without significantly delaying tumor growth (Figure 6D and Supplementary Figure 4C). These tumor rejection rates did not correlate with a differential ability to infiltrate tumor sites, since cells expressing VHL-sensitive HIF-2a (PPN and PPA) infiltrated tumors at the same rate as controls, while cells expressing VHL-insensitive HIF-2a (AAN and AAA) failed to infiltrate the tumor site (Supplementary Figure 4D-F). Infiltration of endogenous CD8+ T cells was unaltered (Supplementary Figure 4G). These experiments reveal an unexpected role of the $\mathrm{FIH}$ hydroxylation site on the HIF-2a 
401 protein for the in vivo anti-tumor function of CD8+ T cells, and indicate an important

402 role for oxygen-mediated transcriptional control of HIF-2a that is qualitatively different

403 from the role played by the VHL pathway.

404 Human CD8+ T cells co-expressing a CAR and FIH-insensitive HIF-2a have

405 increased cytolytic activity against lymphoma cells.

406 To test whether HIF-2a expression could improve the anti-tumor function of human

407 therapeutic T cells we designed a vector encoding an anti-CD19 CAR alone or in

408 combination with FIH-insensitive HIF-2a (Figure 7A and Supplementary Figure 5A).

409 CD8+ T cells purified from multiple human PBMC donors were successfully

410 transduced with CAR vectors as measured by GFP expression (Figure 7B) and

411 consistently showed increased CCR7 levels (Supplementary Figure 5B) in agreement

412 with the RNAseq analysis of mouse CD8+ T cells (Figure 3A). Cytolytic function of

413 CAR-transduced CD8+ T cells against Raji (CD19+) lymphoma cells was significantly

414 increased when HIF-2a was co-expressed (Figure 7C and Supplementary Figure 5C).

415 This result replicates the observations in mouse cells and further supports the

416 translational potential of ectopic expression of HIF-2a in improving the anti-tumor 417 efficacy of T cell products. 


\section{Discussion}

420 In this study we set out to determine if ectopic HIF expression can be used to increase

421 the anti-tumor efficacy of therapeutic CD8+ T cells with the ultimate goal of improving

422 adoptive T-cell therapy protocols for cancer. Retroviral vectors are currently used to

423 deliver ectopic expression of cancer antigen-specific TCRs or CARs to T cells and can

424 be easily modified to deliver additional proteins $(7,8)$. Previous studies employing T425 cell specific deletion of VHL (21), PHDs (22), ARNT (23), HIF-1a, and HIF-2a (24) or 426 hypoxic-priming (20) of CD8+ T cells laid the groundwork for this study by showing

427 that HIF activity drives cytotoxic differentiation and in vivo anti-tumor function.

428 Here we took an agnostic approach regarding which of the two main HIF isoforms and

429 which oxygen-dependent suppression mechanisms could most potently boost anti430 tumor effects by T cells. Previous studies would place non-degradable HIF-1a as the 431 strongest candidate for over-expression, given that VHL- and PHD-null T cells reject 432 tumors more efficiently(21,22), while HIF-1a-null $\mathrm{T}$ cells perform quite poorly in 433 immunotherapy models(24).

434 Our findings reveal that in an ectopic expression setting it is HIF-2a, and not HIF-1a, 435 that is able to most potently boost CD8+ T-cell anti-tumor cytotoxicity. Ectopic HIF-2a 436 was able to elicit broad changes in gene expression by altering the $\mathrm{T}$ cell transcription 437 factor network, irrespective of VHL and FIH suppression. However, the magnitude of 438 change in gene expression was typically higher when HIF-2a was resistant to VHL439 mediated proteolytic degradation. The transcripts altered by HIF-2a extend beyond 440 classical HIF target genes. This is likely due to altered expression of a network of 441 transcriptional modulators, many of them known to have implications for CD8+ T-cell 442 differentiation, including Tcf7, Nr4a1, Nr4a3, Tox and Eomes, all of which drive 
443 memory and/or exhaustion phenotypes, and are downregulated by HIF-2a. Ectopic

444 HIF-2a expression does not result in a gene signature that clearly identifies a memory,

445 effector or exhausted population, generating instead an unconventional phenotype

446 with upregulation of co-stimulators (4-1BB, ICOS), effector proteins (GZMB, Perforin),

447 but also co-inhibitors (CTLA-4, LAG3) and downregulation of IFN $\gamma$.

448 While transcriptional changes detected by RNAseq were largely replicated at protein

449 level, it was at the functional level that oxygen-dependent regulation of HIF-2a proved

450 to be most important. Proteolytic-resistant HIF-2a (AAN and AAA) severely impaired

451 T cell function by restricting proliferation, causing TCR downregulation and decreased

452 IFN $\gamma$ secretion. These results are surprising given the greater anti-tumor function of

453 VHL- and PHD-null T cells reported previously $(21,22)$. Co-culture with a variety of

454 tumor targets consistently revealed that CD8+ T cells expressing VHL-sensitive (PPN

455 and PPA) HIF-2a had the highest cytolytic function suggesting that intermediate levels

456 of HIF-2a protein offer the most benefit.

457 Regulation of HIF-2a has striking effects in the adoptive T cell therapy models we 458 employed. When transferred to melanoma-bearing mice, CD8+ $\mathrm{T}$ cells expressing 459 HIF-2a proteins that are insensitive to $\mathrm{FIH}$, but sensitive to $\mathrm{VHL}$, provide the best 460 protection against tumor growth. The exact opposite arrangement, FIH-sensitive and 461 VHL-insensitive HIF-2a, results in a complete loss of tumor protection by T cells. This 462 role for FIH hydroxylation was only revealed in an in vivo setting. Transcriptional 463 analysis showed great similarity between the PPN and PPA groups (0.97 Spearman $464 \mathrm{r}$ ) and between the AAN and AAA groups (0.98 Spearman $r$ ) despite hydroxylation at 465 N851 being reported as crucial for the transcriptional activity of HIF-2a. It is possible 466 that the consequences of mutating N851 in HIF-2a only become apparent once T cells 467 are allowed to differentiate in vivo, where they are guided by the varying 

made available under aCC-BY-NC-ND 4.0 International license.

468 microenvironments a $\mathrm{T}$ cell inhabits and transverses, including the tumor 469 microenvironment. An in-depth analysis of such microenvironments would be 470 necessary to determine how T cells expressing FIH-insensitive HIF-2a gain a further 471 advantage in rejecting tumors.

472 As with murine cells, human CD8+ T cells transduced with a CAR-HIF construct 473 containing the PPA configuration showed increased cytolytic function against a B-cell 474 lymphoma line. These results demonstrate that such vectors may be an important and 475 novel addition to the CAR-T armamentarium. 


\section{Acknowledgements}

478 The authors thank Angelika Holler at University College London for providing reagents

479 and discussions, and the Bioinformatics and Expression Analysis (BEA) Core Facility

480 at the Department of Biosciences and Nutrition, which is supported by the board of

481 research at the Karolinska Institute and the research committee at the Karolinska

482 hospital. 


\section{References}

1. June $\mathrm{CH}$, Riddell SR, Schumacher TN. Adoptive cellular therapy: a race to the finish line. Sci Transl Med. 2015;7:280ps7.

2. Zhang T, Cao L, Xie J, Shi N, Zhang Z, Luo Z, et al. Efficiency of CD19 chimeric antigen receptor-modified $T$ cells for treatment of $B$ cell malignancies in phase I clinical trials: a meta-analysis [Internet]. Oncotarget. 2015. Available from:

http://dx.doi.org/10.18632/oncotarget.5582

3. Zhao L, Cao YJ. Engineered T Cell Therapy for Cancer in the Clinic. Front Immunol. 2019;10:2250.

4. Eyquem J, Mansilla-Soto J, Giavridis T, van der Stegen SJC, Hamieh M, Cunanan KM, et al. Targeting a CAR to the TRAC locus with CRISPR/Cas9 enhances tumour rejection. Nature. 2017;543:113-7.

5. Rupp LJ, Schumann K, Roybal KT, Gate RE, Ye CJ, Lim WA, et al. CRISPR/Cas9mediated PD-1 disruption enhances anti-tumor efficacy of human chimeric antigen receptor T cells. Sci Rep. 2017;7:737.

6. Yeku OO, Purdon TJ, Koneru M, Spriggs D, Brentjens RJ. Armored CAR T cells enhance antitumor efficacy and overcome the tumor microenvironment [Internet]. Scientific Reports. 2017. Available from: http://dx.doi.org/10.1038/s41598-017-10940-8

7. Martinez M, Moon EK. CAR T Cells for Solid Tumors: New Strategies for Finding, Infiltrating, and Surviving in the Tumor Microenvironment [Internet]. Frontiers in Immunology. 2019. Available from: http://dx.doi.org/10.3389/fimmu.2019.00128

8. Brandt LJB, Barnkob MB, Michaels YS, Heiselberg J, Barington T. Emerging Approaches for Regulation and Control of CAR T Cells: A Mini Review [Internet]. Frontiers in Immunology. 2020. Available from: http://dx.doi.org/10.3389/fimmu.2020.00326

9. Stavrou M, Philip B, Traynor-White C, Davis CG, Onuoha S, Cordoba S, et al. A Rapamycin-Activated Caspase 9-Based Suicide Gene. Mol Ther. 2018;26:1266-76.

10. Lynn RC, Weber EW, Sotillo E, Gennert D, Xu P, Good Z, et al. c-Jun overexpression in CAR T cells induces exhaustion resistance [Internet]. Nature. 2019. page 293-300. Available from: http://dx.doi.org/10.1038/s41586-019-1805-z

11. Dengler VL, Galbraith M, Espinosa JM. Transcriptional regulation by hypoxia inducible factors. Crit Rev Biochem Mol Biol. 2014;49:1-15.

12. Schödel J, Oikonomopoulos S, Ragoussis J, Pugh CW, Ratcliffe PJ, Mole DR. Highresolution genome-wide mapping of HIF-binding sites by ChIP-seq [Internet]. Blood. 2011. page e207-17. Available from: http://dx.doi.org/10.1182/blood-2010-10-314427

13. Haase V. The VHL Tumor Suppressor: Master Regulator of HIF [Internet]. Current Pharmaceutical Design. 2009. page 3895-903. Available from: http://dx.doi.org/10.2174/138161209789649394

14. Maxwell PH, Wiesener MS, Chang GW, Clifford SC, Vaux EC, Cockman ME, et al. The tumour suppressor protein VHL targets hypoxia-inducible factors for oxygen-dependent 
proteolysis. Nature. 1999;399:271-5.

15. Lando $\mathrm{D}$. $\mathrm{FIH}-1$ is an asparaginyl hydroxylase enzyme that regulates the transcriptional activity of hypoxia-inducible factor [Internet]. Genes \& Development. 2002. page 146671. Available from: http://dx.doi.org/10.1101/gad.991402

16. Mahon PC, Hirota K, Semenza GL. FIH-1: a novel protein that interacts with HIF-1alpha and $\mathrm{VHL}$ to mediate repression of HIF-1 transcriptional activity. Genes Dev. 2001;15:2675-86.

17. Li Y, Patel SP, Roszik J, Qin Y. Hypoxia-Driven Immunosuppressive Metabolites in the Tumor Microenvironment: New Approaches for Combinational Immunotherapy. Front Immunol. 2018;9:1591.

18. Corbet $\mathrm{C}$, Feron $\mathrm{O}$. Tumour acidosis: from the passenger to the driver's seat [Internet]. Nature Reviews Cancer. 2017. page 577-93. Available from:

http://dx.doi.org/10.1038/nrc.2017.77

19. Sitkovsky MV, Kjaergaard J, Lukashev D, Ohta A. Hypoxia-Adenosinergic Immunosuppression: Tumor Protection by T Regulatory Cells and Cancerous Tissue Hypoxia [Internet]. Clinical Cancer Research. 2008. page 5947-52. Available from: http://dx.doi.org/10.1158/1078-0432.ccr-08-0229

20. Gropper Y, Feferman T, Shalit T, Salame T-M, Porat Z, Shakhar G. Culturing CTLs under Hypoxic Conditions Enhances Their Cytolysis and Improves Their Anti-tumor Function. Cell Rep. 2017;20:2547-55.

21. Doedens AL, Phan AT, Stradner MH, Fujimoto JK, Nguyen JV, Yang E, et al. Hypoxiainducible factors enhance the effector responses of CD8 T cells to persistent antigen [Internet]. Nature Immunology. 2013. page 1173-82. Available from:

http://dx.doi.org/10.1038/ni.2714

22. Clever D, Roychoudhuri R, Constantinides MG, Askenase MH, Sukumar M, Klebanoff CA, et al. Oxygen Sensing by T Cells Establishes an Immunologically Tolerant Metastatic Niche. Cell. 2016;166:1117-31.e14.

23. Finlay DK, Rosenzweig E, Sinclair LV, Feijoo-Carnero C, Hukelmann JL, Rolf J, et al. PDK1 regulation of mTOR and hypoxia-inducible factor 1 integrate metabolism and migration of CD8 T cells [Internet]. The Journal of Experimental Medicine. 2012. page 2441-53. Available from: http://dx.doi.org/10.1084/jem.20112607

24. Palazon A, Tyrakis PA, Macias D, Veliça P, Rundqvist H, Fitzpatrick S, et al. An HIF$1 \alpha /$ VEGF-A Axis in Cytotoxic T Cells Regulates Tumor Progression. Cancer Cell. 2017;32:669-83.e5.

25. Hukelmann JL, Anderson KE, Sinclair LV, Grzes KM, Murillo AB, Hawkins PT, et al. The cytotoxic T cell proteome and its shaping by the kinase mTOR. Nat Immunol. 2016;17:104-12.

26. Hermans D, Gautam S, García-Cañaveras JC, Gromer D, Mitra S, Spolski R, et al. Lactate dehydrogenase inhibition synergizes with IL-21 to promote CD8 T cell stemness and antitumor immunity. Proc Natl Acad Sci U S A [Internet]. 2020; Available from: http://dx.doi.org/10.1073/pnas.1920413117

27. Khan AB, Carpenter B, Santos E Sousa P, Pospori C, Khorshed R, Griffin J, et al. Redirection to the bone marrow improves $T$ cell persistence and antitumor functions. $J$ 
Clin Invest. 2018;128:2010-24.

28. Danilo M, Chennupati V, Silva JG, Siegert S, Held W. Suppression of Tcf1 by Inflammatory Cytokines Facilitates Effector CD8 T Cell Differentiation. Cell Rep. 2018;22:2107-17.

29. Chen Z, Ji Z, Ngiow SF, Manne S, Cai Z, Huang AC, et al. TCF-1-Centered Transcriptional Network Drives an Effector versus Exhausted CD8 T Cell-Fate Decision [Internet]. Immunity. 2019. page 840-55.e5. Available from: http://dx.doi.org/10.1016/j.immuni.2019.09.013

30. Khan O, Giles JR, McDonald S, Manne S, Ngiow SF, Patel KP, et al. TOX transcriptionally and epigenetically programs CD8 T cell exhaustion. Nature. 2019;571:211-8.

31. Chen J, López-Moyado IF, Seo H, Lio C-WJ, Hempleman LJ, Sekiya T, et al. NR4A transcription factors limit CAR T cell function in solid tumours. Nature. 2019;567:530-4.

32. Li J, He Y, Hao J, Ni L, Dong C. High Levels of Eomes Promote Exhaustion of Antitumor CD8 T Cells. Front Immunol. 2018;9:2981.

33. Ke X, Fei F, Chen Y, Xu L, Zhang Z, Huang Q, et al. Hypoxia upregulates CD147 through a combined effect of HIF-1 $\alpha$ and Sp1 to promote glycolysis and tumor progression in epithelial solid tumors. Carcinogenesis. 2012;33:1598-607. 
bioRxiv preprint doi: https://doi.org/10.1101/2020.06.18.159137; this version posted July 2, 2020. The copyright holder for this preprint (which was not certified by peer review) is the author/funder, who has granted bioRxiv a license to display the preprint in perpetuity. It is made available under aCC-BY-NC-ND 4.0 International license.

Modified HIF expression in CD8+ T cells increases anti-tumor efficacy

Veliça et al.

\section{Figures}


A

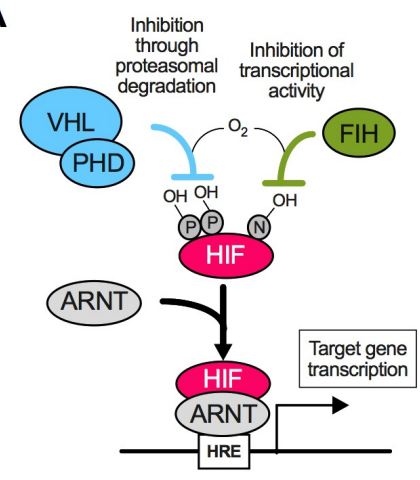

B

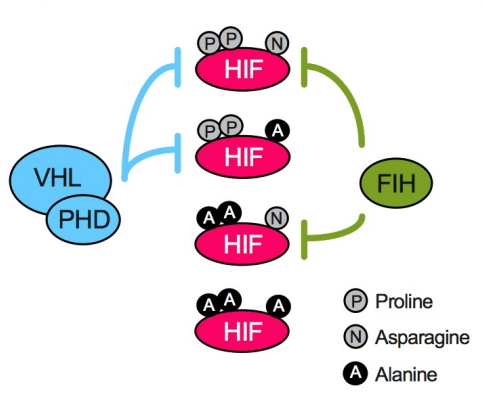

C

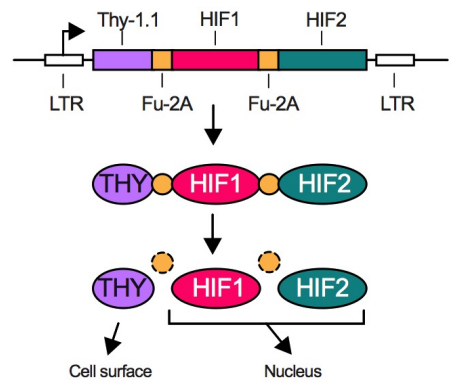

D
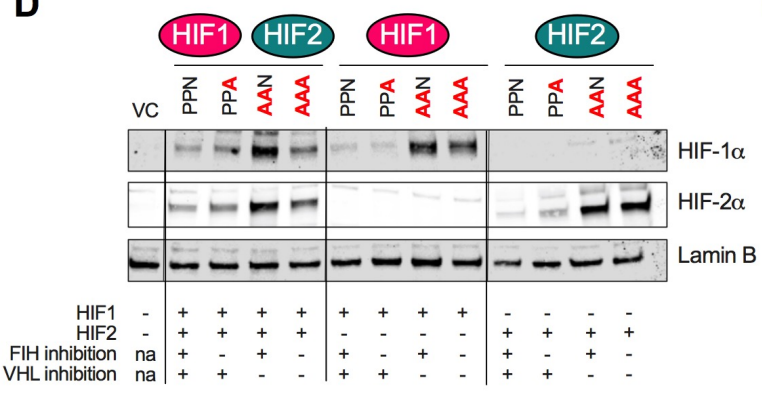

HEK cells (nuclear)
E

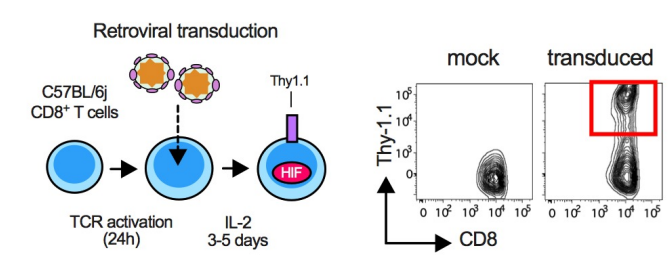

G

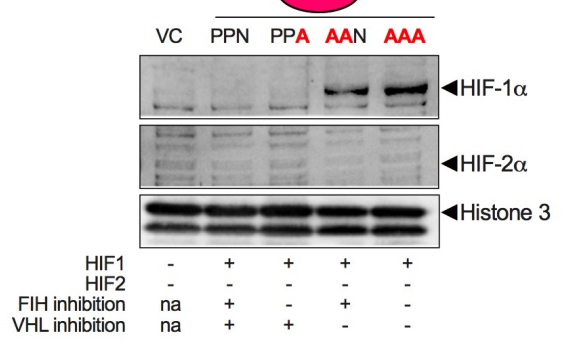

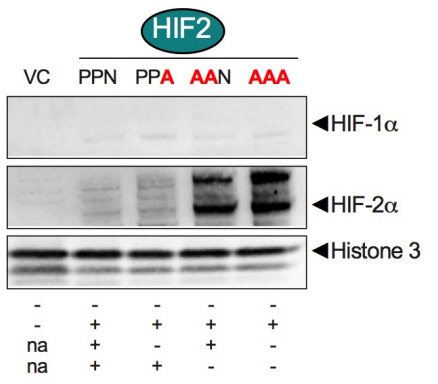

Thy $-1.1^{+} \mathrm{CD}^{+} \mathrm{T}$ cells (nuclear)

Figure 1. Design and validation of retroviral vectors to drive ectopic expression of HIF proteins in mouse CD8+ $T$ cells

(A) HIF transcription factors are post-translationally regulated. Oxygen-dependent hydroxylation at conserved proline (P) residues by proly-hydroxylases (PHD) results in Von Hippel-Lindau (VHL)mediated proteasomal degradation. Hydroxylation at a conserved asparagine $(\mathrm{N})$ residue by Factor Inhibiting HIF (FIH) prevents recruitment of the coactivator p300/CBP resulting in inhibited transcriptional activity. Once released from VHL/PHD and FIH repression, HIF proteins heterodimerize with Aryl hydrocarbon Receptor Nuclear Translocator (ARNT), translocate to the nucleus, bind hypoxiaresponsive elements (HRE) and initiate transcription of target genes.

(B) Mutation of key amino acid residues modulates HIF regulation. Mutation of conserved prolines (P402, P577 in mouse HIF-1 $\alpha$; P405, P530 in mouse HIF-2a) and of conserved asparagine (N813 in mouse HIF-1 $\alpha$ and N851 in mouse HIF-2 $\alpha$ ) into alanine (A) prevents hydroxylation by PHD and FIH, respectively.

(C) Retroviral vector design for ectopic HIF expression. After genomic integration the retroviral long terminal repeat (LTR) promoter drives expression of a polycistronic peptide containing Thy-1.1 (THY), HIF-1 $\alpha$ (HIF-1a) and HIF-2 $\alpha$ (HIF-2a) interspersed with furin cleavage sites and self-cleaving picornavirus $2 \mathrm{~A}$ sites. Post-translational processing results in separation of the elements. Surface and nuclear localization sequences target Thy-1.1 to the cell surface and HIF isoforms to the nucleus, respectively. 
bioRxiv preprint doi: https://doi.org/10.1101/2020.06.18.159137; this version posted July 2, 2020. The copyright holder for this preprint (which was not certified by peer review) is the author/funder, who has granted bioRxiv a license to display the preprint in perpetuity. It is made available under aCC-BY-NC-ND 4.0 International license.

(D) Nuclear extracts from HEK cells transfected with vectors encoding HIF-1 $\alpha$ alone, HIF-2 $\alpha$ alone or both probed for mouse HIF-1 $\alpha$, HIF-2 $\alpha$ and Lamin B. Vector control (VC) encodes Thy-1.1 alone.

(E) CD8+ T-cell transduction scheme. Primary CD8+ T cells were purified from mouse (C57BL/6j) splenocytes and activated by T-cell receptor (TCR) triggering for 24 hours before transduction with retroviral particles. Transduced T cells were expanded in the presence of IL-2 for further 3-5 days before subsequent analysis.

(F) Example of CD8+ T-cell transduction. Representative flow cytometry plot showing retrovirally (RV)transduced cells expressing Thy-1.1 on the cell surface (red box).

(G) Nuclear extracts from Thy-1.1+ CD8+ T cells transfected with vectors encoding HIF-1 $\alpha$ or HIF-2 $\alpha$ probed for mouse HIF-1 $\alpha$, HIF-2 $\alpha$ and Histone 3. Vector control (VC) encodes Thy-1.1 alone. 
A

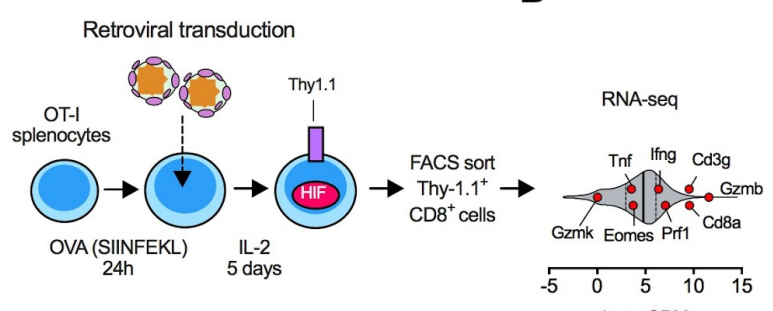

C

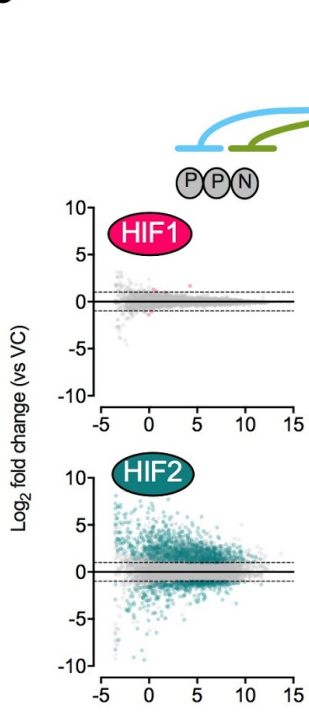

D

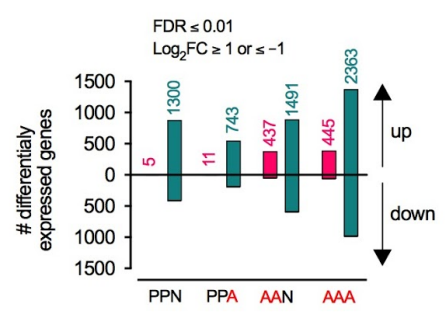

E

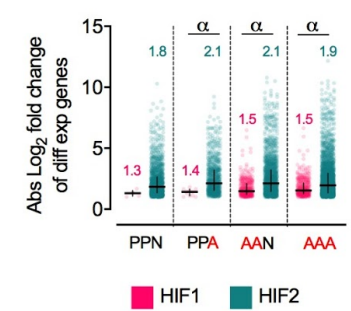

B

$\log _{2}$ CPM 
bioRxiv preprint doi: https://doi.org/10.1101/2020.06.18.159137; this version posted July 2, 2020. The copyright holder for this preprint (which was not certified by peer review) is the author/funder, who has granted bioRxiv a license to display the preprint in perpetuity. It is made available under aCC-BY-NC-ND 4.0 International license.

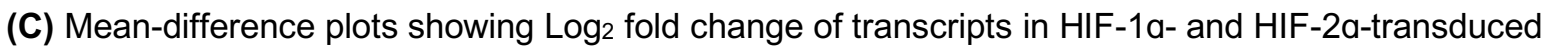
relative to vector control (VC)-transduced CD8+ T cells. Pink and green circles: differentially expressed transcripts as defined by a false discovery rate $(F D R)<0.01$ and $\log _{2}$ fold change $>1$ or

$<-1$. Grey circles: non-differentially expressed transcripts.

(D) Bar chart summarizing total number of up- and down-regulated transcripts. Values over bars: total number of differentially expressed genes.

(E) Scattered dot plot showing absolute Log $_{2}$ fold change of differentially expressed transcripts in each transduction. Lines: median and interquartile range. Values over plots: median Log $\mathrm{g}_{2}$ fold change. a, $P<0.01$; Kruskal-Wallis with Dunn's multiple comparison test.

(F) Heatmap representing correlation in transcript frequency between HIF-1a and HIF-2a-transduced CD8+ T cells. Values in boxes: Spearman's rank correlation coefficient. 
bioRxiv preprint doi: https://doi.org/10.1101/2020.06.18.159137; this version posted July 2, 2020. The copyright holder for this preprint (which was not certified by peer review) is the author/funder, who has granted bioRxiv a license to display the preprint in perpetuity. It is made available under aCC-BY-NC-ND 4.0 International license.

A
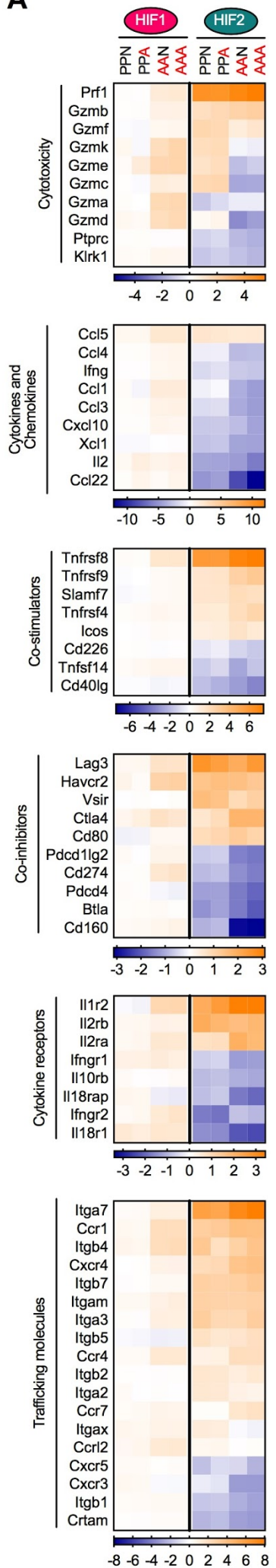

B
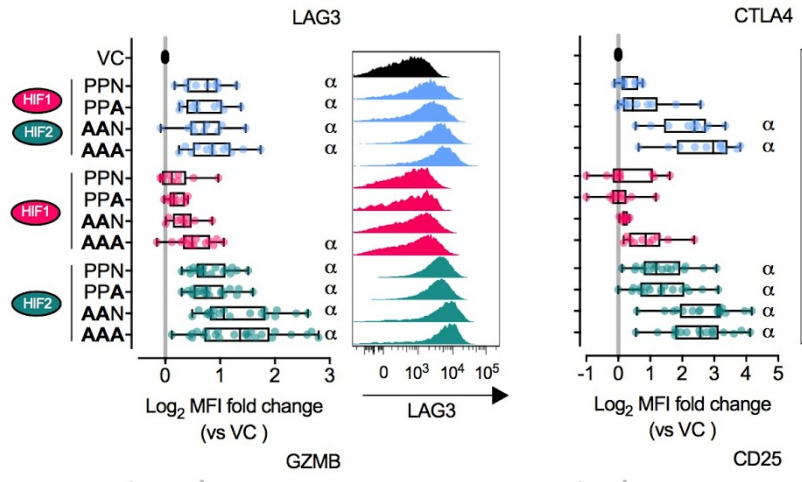

Log $_{2} \mathrm{MFI}$ fold change

(vs VC)

$\mathrm{CD} 25$
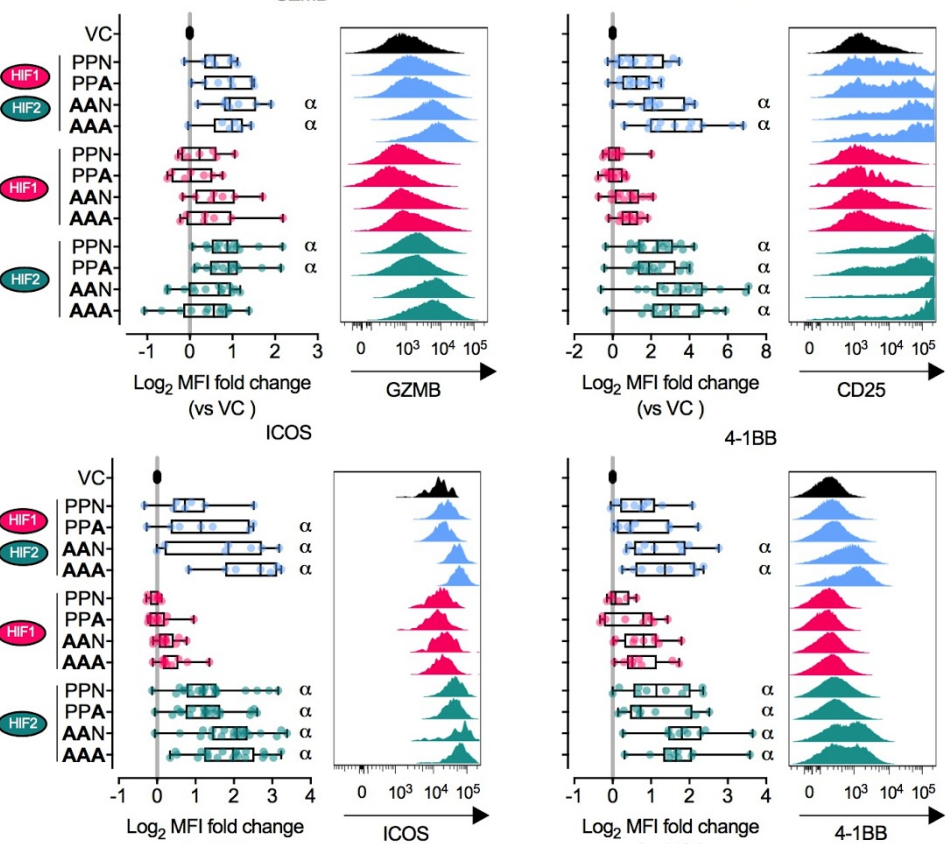

$\cos$

(vs VC)
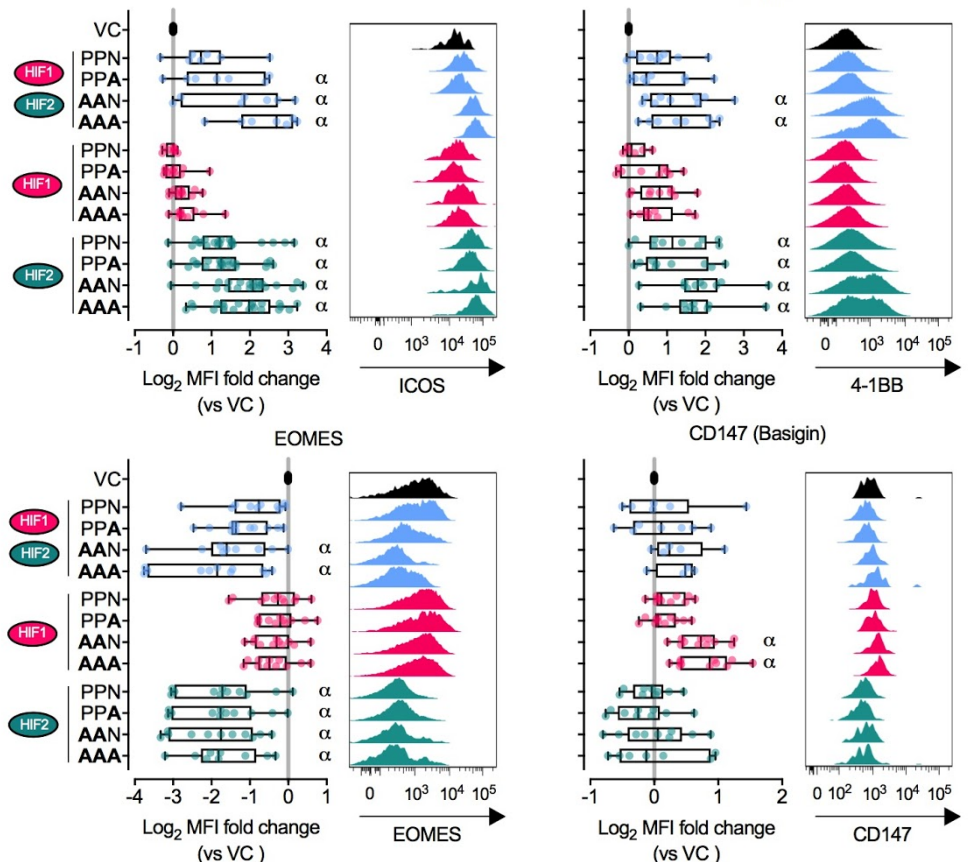

(vs VC)

CD147 (Basigin)

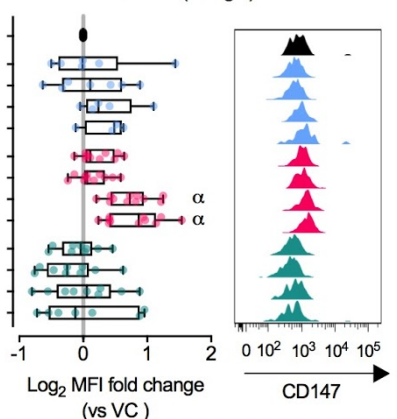

vector control (VC)

$\alpha P<0.01$ relative to $\mathrm{VC}$

HIF1 + HIF2

HIF1

HIF2 
bioRxiv preprint doi: https://doi.org/10.1101/2020.06.18.159137; this version posted July 2, 2020. The copyright holder for this preprint (which was not certified by peer review) is the author/funder, who has granted bioRxiv a license to display the preprint in perpetuity. It is made available under aCC-BY-NC-ND 4.0 International license.

Figure 3. Effects of ectopic expression of HIF-1a or HIF-2a in genes involved in CD8+ T-cell function

(A) Heatmaps showing Log 2 fold change of transcripts involved in functional aspects of CD8+ T cells. (B) Expression of differentiation markers determined by flow cytometry in CD8+ T cells transduced with vectors encoding HIF-1a and HIF-2a, HIF-1a alone or HIF-2a alone (day 3 to 5 posttransduction). Data expressed as $\log _{2}$ fold change of median fluorescence intensity (MFI) relative to VC-transduced cells. Each data point represents an independent transduction $(n=4-24)$. Results are pooled from a minimum of two independent experiments. $\alpha, P<0.01$; one-way ANOVA with Dunnett's multiple comparison test relative to VC. Histograms are representative flow cytometry plots for each parameter and are pre-gated on live, singlet, CD8+ Thy-1.1+ events. 
A
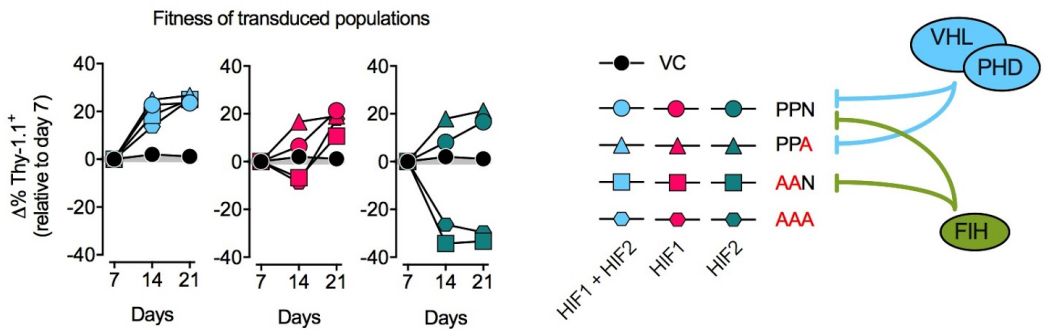

B

C
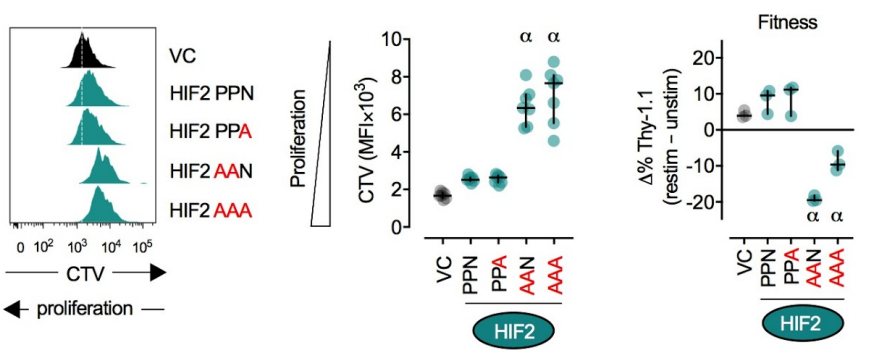

D

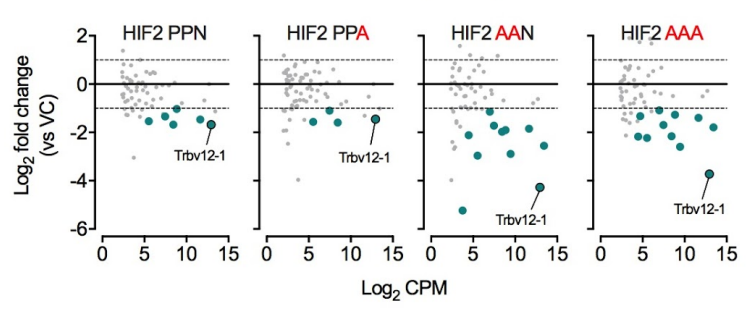

$\mathbf{F}$

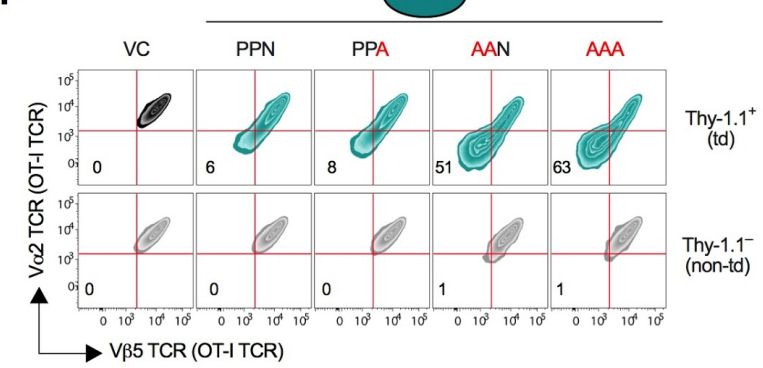

E

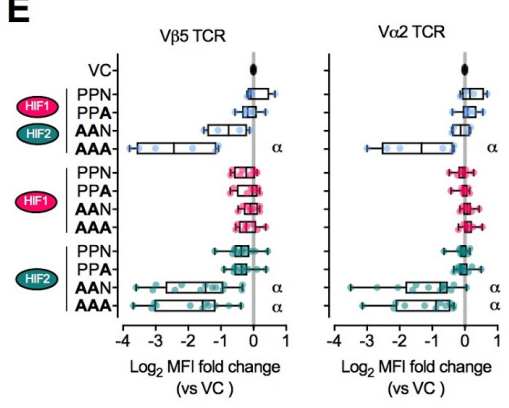

G

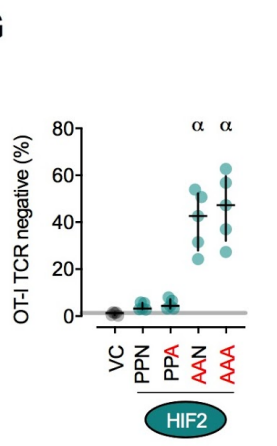

H

Polyclonal
CD8+T cells

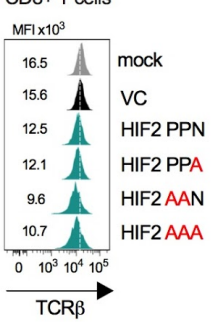

Figure 4. Ectopic expression of VHL-insensitive HIF-2a reduces CD8+ T-cell proliferation and drives TCR loss

(A) Fitness of HIF-transduced CD8+ T cells over time. CD8+ T cells were transduced with HIF-1a and HIF-2a-coding vectors and cultured for 21 days in the presence of IL-2. Cells were restimulated with CD3/CD28 beads on days 7 and 14. Fitness was calculated as the difference in $\%$ of Thy- $1.1^{+}$cells in culture relative to day $7\left(\Delta \%\right.$ Thy $\left.-1.1^{+}\right)$. VC: vector control.

(B) Proliferation of HIF-2a-transduced CD8+ T cells. Cells were loaded with CellTrace Violet (CTV) proliferation dye 6 days after transduction and were restimulated with aCD3/CD28 beads for 3 days. Proliferation was determined by CTV dilution in flow cytometry. Left: representative histograms pregated on live, singlet, CD8+. Thy-1.1+ events. Right: summary data showing CTV mean fluorescence intensity (MFI). $n=7$ independent transductions. Lines: median and interquartile range. 
bioRxiv preprint doi: https://doi.org/10.1101/2020.06.18.159137; this version posted July 2, 2020. The copyright holder for this preprint (which was not certified by peer review) is the author/funder, who has granted bioRxiv a license to display the preprint in perpetuity. It is made available under aCC-BY-NC-ND 4.0 International license.

(C) Fitness of HIF-2a-transduced cells after restimulation. Fitness was calculated as the difference in $\%$ of Thy $-1.1^{+}$cells in culture between restimulated and unstimulated cultures $\left(\Delta \%\right.$ Thy-1.1 $\left.1^{+}\right) . n=3$ independent transductions. Lines: median and interquartile range.

(D) Mean-difference plots showing $\log _{2}$ fold change of TCR chain-coding transcripts in HIF-2atransduced relative to VC-transduced CD8+ T cells. Green circles: differentially expressed transcripts as defined by a false discovery rate (FDR) $<0.01$ and $\log _{2}$ fold change $>1$ or $<-1$. Grey circles: nondifferentially expressed transcripts. Trbv12-1 codes the V $\beta 5$ segment of the TCR $\beta$ chain.

(E) Expression of TCR V $\alpha 2$ and TCR V $\beta 5$ chains determined by flow cytometry in OT-I CD8+ T cells transduced with vectors encoding HIF-1a and HIF-2a, HIF-1a alone or HIF-2a alone (day 3 to 5 posttransduction). Data expressed as $\log _{2}$ fold change of MFI relative to $\mathrm{VC}$-transduced cells. Each data point represents an independent transduction $(n=4-24)$. Results are pooled from a minimum of two independent experiments.

(F) Surface expression of OT-I TCR chains in HIF-2a-transduced OT-I cells on day 4 post-transduction. Flow cytometry zebra plots pre-gated on live, singlet, CD8+. events showing surface expression of OTI TCR V 22 and TCR V $\beta 5$ chains in transduced (Thy-1.1+; top row) and non-transduced (Thy-1.1-; bottom row). Values are percentage within the double-negative quadrant.

(G) Frequency of TCR-negative cells. $n=5$ independent transductions. Lines: median and interquartile range. Grey horizontal line: median of VC group.

(H) Surface expression of the TCR $\beta$ constant chain in polyclonal CD8+ T cells transduced with HIF-2acoding vectors. Values in histograms are MFI $\times 10^{3}$.

$\alpha, P<0.01$; one-way ANOVA with Dunnett's multiple comparison test relative to VC. 
A

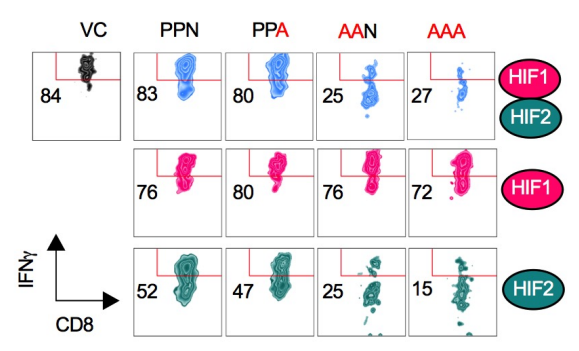

C

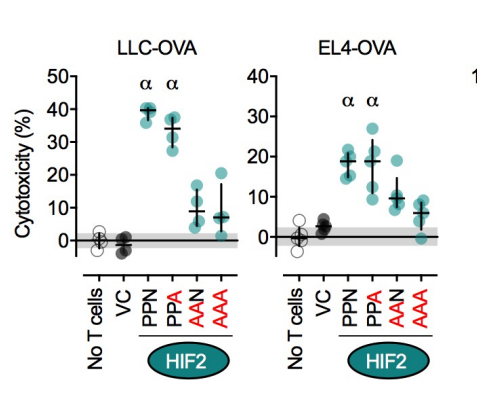

B

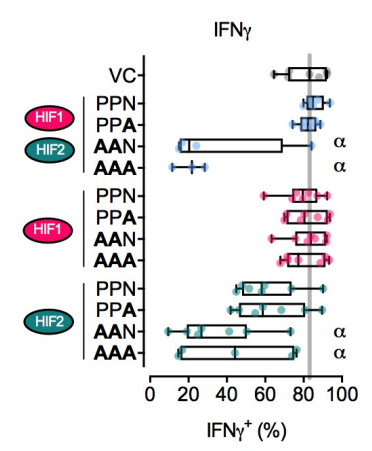

Figure 5. Ectopic expression of HIF-2a enhances cytotoxicity against tumor cells

(A) Interferon-y (IFNY) secretion determined by intracellular cytokine flow cytometry in OT-I CD8+ T cells transduced with vectors encoding HIF-1a and HIF-2a, HIF-1a alone or HIF-2a alone and restimulated for 4 hours with $1 \mu$ M OVA (SIINFEKL) peptide. Values are the percentage within the IFNy ${ }^{+}$ gate. Pre-gated on live, singlet, CD8+. Thy-1.1+ events

(B) Summary data expressed as \% IFNY ${ }^{+}$cells. Each data point represents an independent transduction $(n=3-7)$. Results are pooled from a minimum of two independent experiments.

(C) OT-I CD8+ T cells transduced with HIF-2a-coding vectors were Thy-1.1-enriched and co-cultured with OVA-expressing EL4 thymoma (EL4-OVA) or Lewis Lung Carcinoma (LLC-OVA) or B16-F10 melanoma (B16-F10-OVA) tumor cells at an effector:target ratio of 1:1 (EL4, LLC) or 1:5 (B16-F10). Cytotoxicity was assessed after 20 hours of co-culture at $21 \%, 5 \%$ or $1 \% \mathrm{O}_{2} . n=4-5$ technical replicates.

Lines: median and interquartile range. Grey horizontal area: interquartile range of no $\mathrm{T}$ cell control. $\alpha, P<0.01$; one-way ANOVA with Dunnett's multiple comparison test relative to VC. 
A

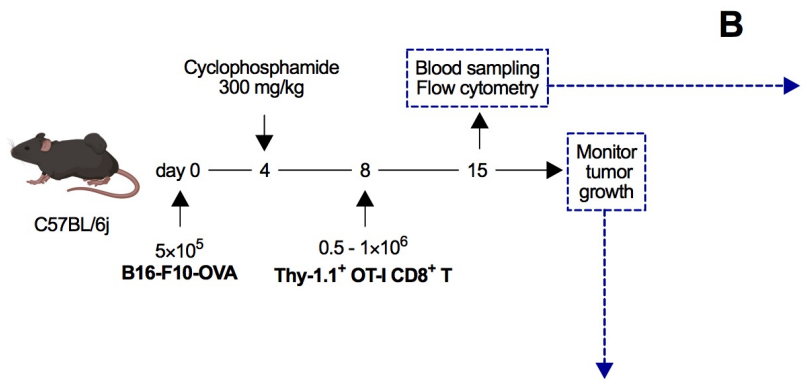

B

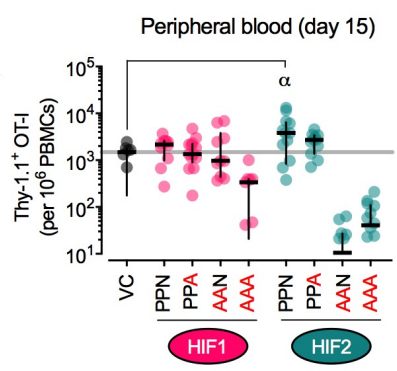

C
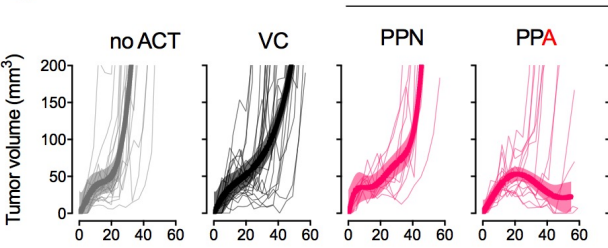

HIF1)

HIF2
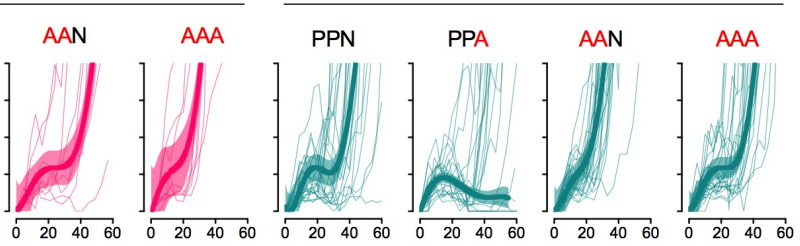

D
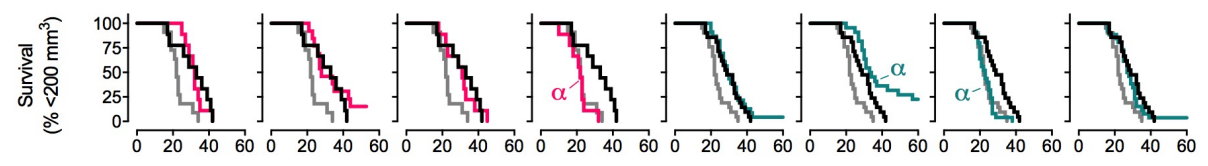
Days since tumor injection
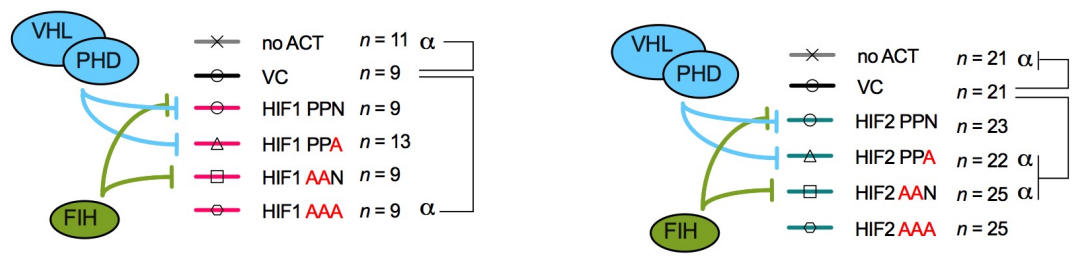

Figure 6. Adoptive transfer of CD8+ T cells ectopically expressing FIH-insensitive HIF-2a results in delayed tumor growth and increased survival rate.

(A) Adoptive cell therapy (ACT) model. C57BL/6j mice were injected subcutaneously with $5 \times 10^{5} \mathrm{OVA}$ expressing B16-F10 (B16-F10-OVA) and 4 days later were lymphodepleted with $300 \mathrm{mg} / \mathrm{kg}$

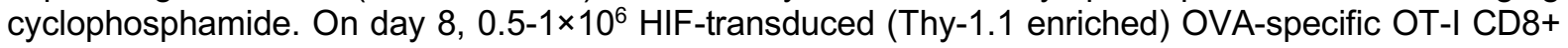
T cells were adoptively transferred into tumor-bearing mice. Peripheral blood was sampled at day 15 and analysed by flow cytometry. Tumor growth was monitored every 2-3 days until day 60 .

(B) Frequency of HIF-transduced OT-I cells per million PBMCs in peripheral blood. $n=8-13$ animals pooled from two independent experiments. Grey horizontal line: median of $V C$ group. $\alpha, P<0.01$; oneway ANOVA with Dunnett's multiple comparison test relative to VC.

(C) B16-F10-OVA tumor growth after ACT. B16-F10-OVA tumor volume measured until day 60 after mice received VC- HIF-1a- or HIF-2a-transduced OT-I cells on day 8. Thin lines: tumor growth from individual animals. Thick line: centred sixth order polynomial curve. Shaded area: $99 \%$ confidence level interval. $n=9-25$ animals per group pooled from two (HIF-1a) or four (HIF-2a) independent experiments.

(D) Survival curves for tumor growth shown in (D). Threshold for survival was set at $200 \mathrm{~mm}^{3}$. Grey line: no ACT. Black line: ACT of VC-transduced OT-I. Pink or green lines: ACT of HIF-1a- or HIF-2atransduced OT-I, respectively. $\alpha, P<0.01$; log-rank (Mantel-Cox) test relative to VC. 
A

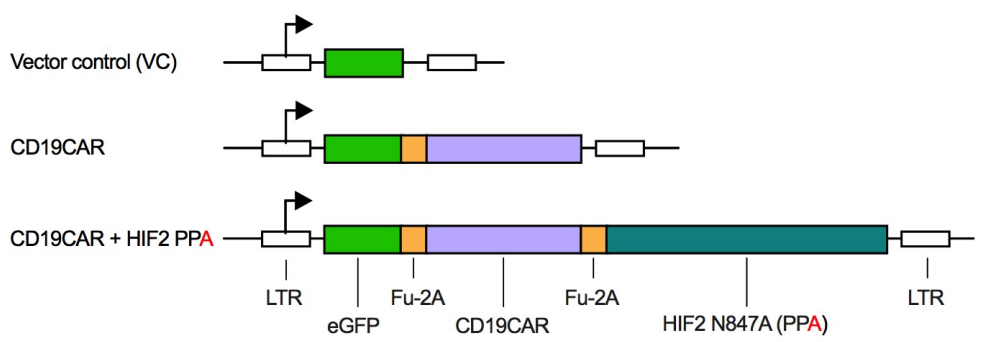

B
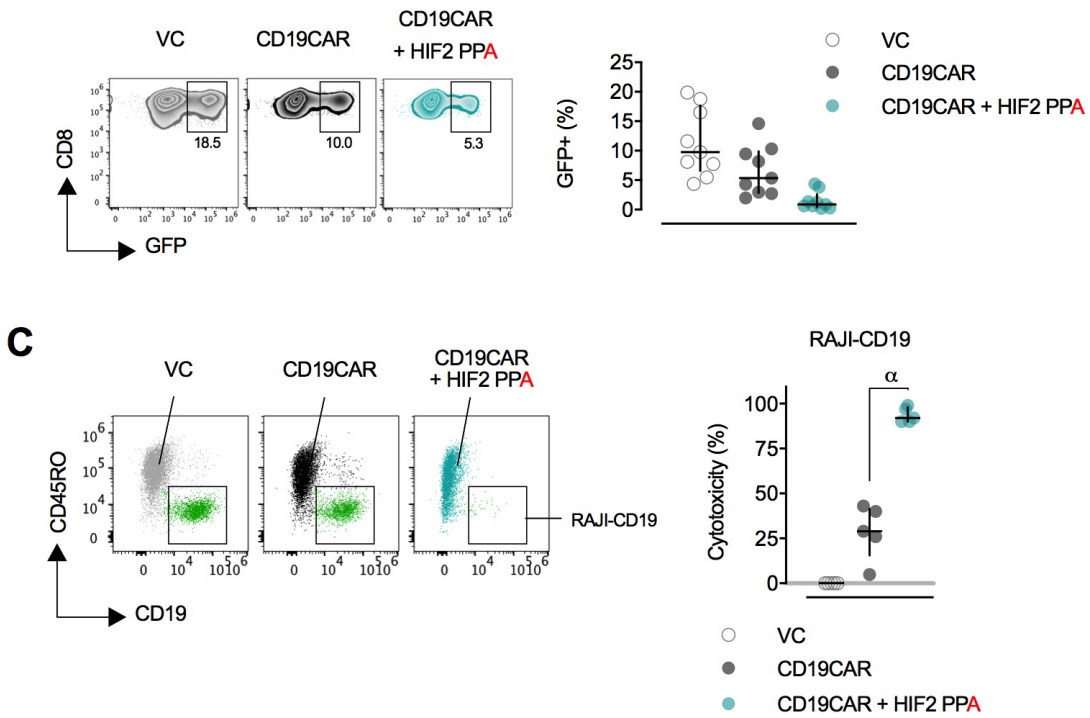

Figure 7. FIH-insensitive HIF-2a increases cytotoxicity of human CD8+ CAR-T cells against lymphoma cells.

(A) Retroviral vector design for co-expression of an anti-CD19 CAR and FIH-insensitive (N847A; PPA) human HIF-2a. LTR: long terminal repeats. Fu-2A: furin and picornavirus $2 A$ self-cleaving sequence.

(B) Representative flow cytometry plots of transduced (GFP+) human CD8+ T cells pre-gated on live, singlet, CD8+ events and summary data of transduction efficiency of 9 donors. Lines: median and interquartile range.

(C) Cytotoxicity of VC- or CAR-transduced human CD8+ T cells against GFP+ CD19+ RAJl lymphoma cells after 20 hours of co-culture at a 1:1 effector-to-target ratio. Representative flow cytometry showing transduced (GFP+, CD45RO+) CD8+ T cells and RAJl targets (GFP+, CD19+) after gating on live, singlet GFP+ events. Summary data of specific cytotoxicity of 5 donors. Lines: median and interquartile range.

a, $P<0.01$; one-way ANOVA with Dunnett's multiple comparison test relative to VC. 
bioRxiv preprint doi: https://doi.org/10.1101/2020.06.18.159137; this version posted July 2, 2020. The copyright holder for this preprint (which was not certified by peer review) is the author/funder, who has granted bioRxiv a license to display the preprint in perpetuity. It is made available under aCC-BY-NC-ND 4.0 International license.

Modified HIF expression in CD8+ T cells increases anti-tumor efficacy

Veliça et al.

\section{Supplementary Figures}


A

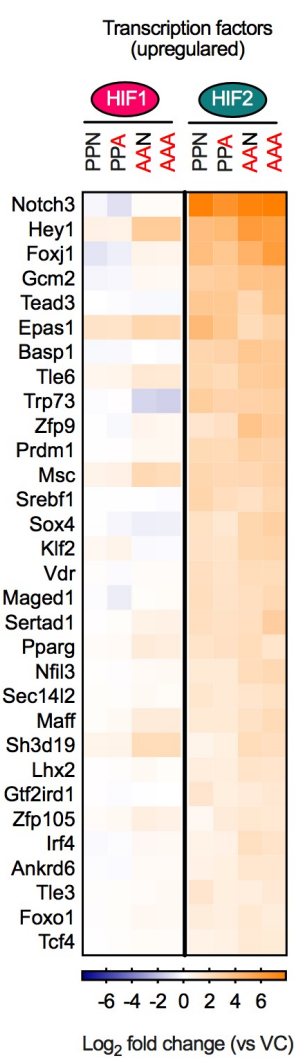

B

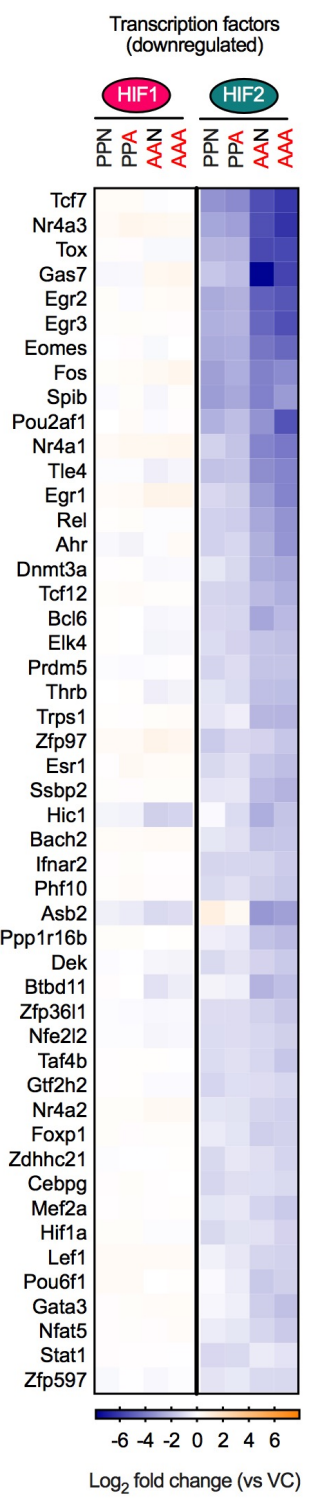

C

Hypoxia response

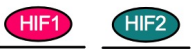

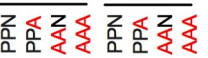

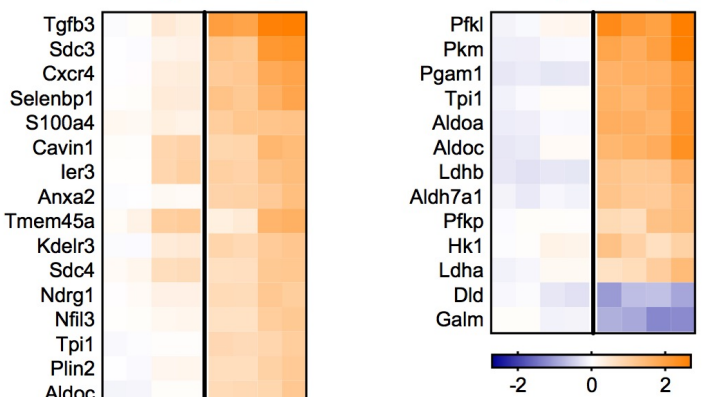

Log $_{2}$ fold change (vs VC)

\section{Supplementary Figure 1. Ectopic expression HIF-2a alters the transcriptional network of CD8+} T cells.

(A) Heatmap showing $\log _{2}$ fold change of upregulated transcripts involved in transcription modulation.

(B) Heatmap showing Log $_{2}$ fold change of downregulated transcripts involved in transcription modulation.

(C) Heatmap showing $\log _{2}$ fold change of deregulated transcripts involved in response to hypoxia.

(D) Heatmap showing $\log _{2}$ fold change of deregulated transcripts involved in glycolysis and gluconeogenesis.

For each heatmap transcripts were included if FDR $<0.01$ and $\log _{2}$ fold change $>1$ or $<-1$ for at least one of the transduced groups. 
A
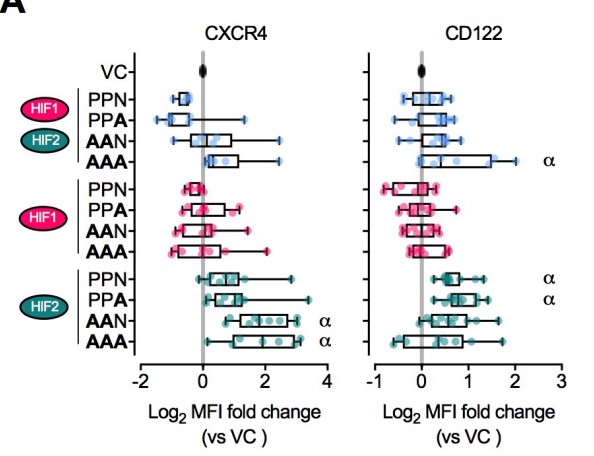

vector control (VC)

HIF1 + HIF2

HIF1

HIF2

$\alpha P<0.01$ relative to $\mathrm{VC}$

B

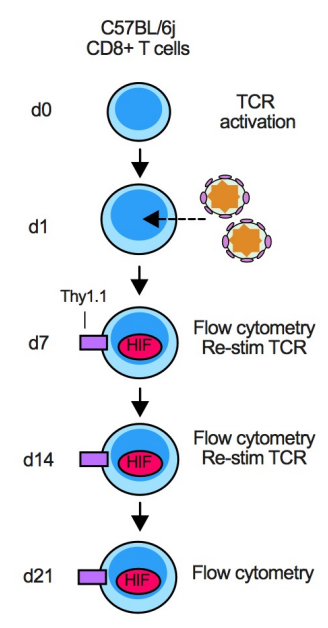

C

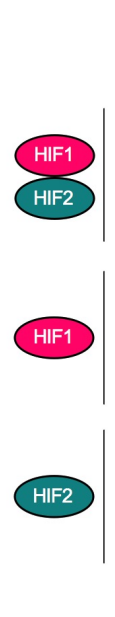

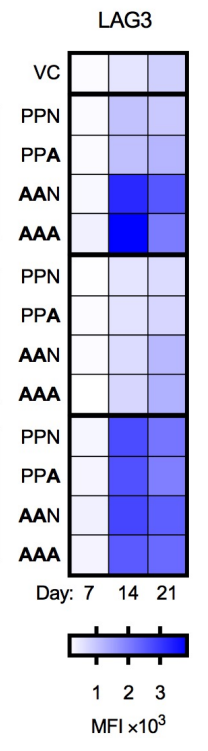
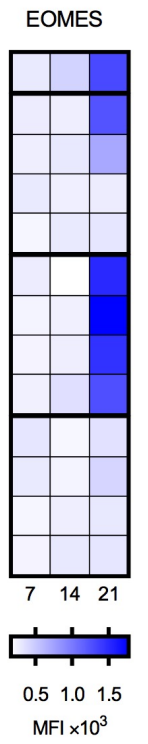
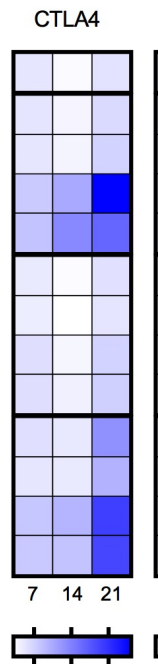

123

$\mathrm{MFI} \times 10^{3}$
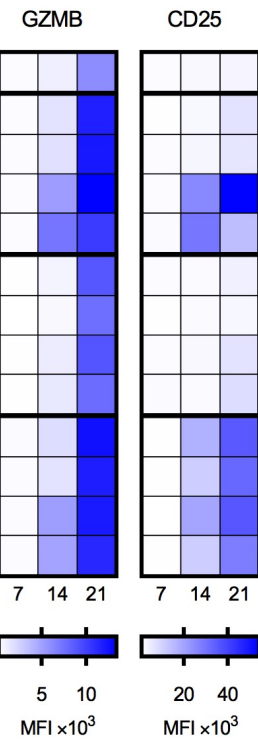
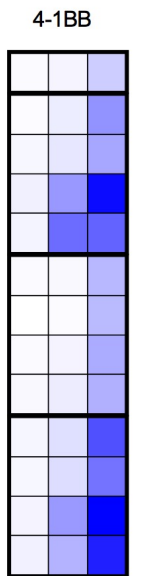

IFN $\gamma$
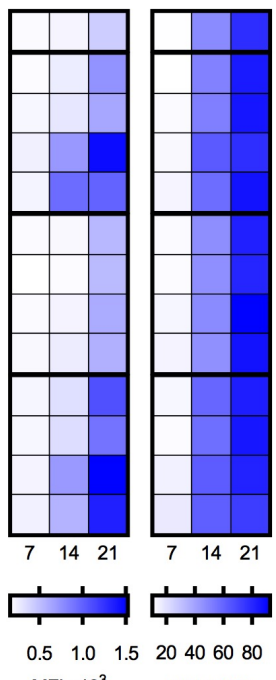

$\mathrm{MFI} \times 10^{3} \quad \mathrm{IFN} \gamma+(\%)$

\section{Supplementary Figure 2. Ectopic HIF expression alters expression of proteins associated with CD8+ T-cell differentiation}

(A) Expression of CXCR4 and CD122 determined by flow cytometry in CD8+ T cells transduced with vectors encoding HIF-1a and HIF-2a, HIF-1a alone or HIF-2a alone (day 3 to 5 post-transduction). PPN - inhibited by VHL and FIH; PPA - inhibited by VHL only; AAN - inhibited by FIH only; AAA - neither VHL nor FIH inhibition. Data expressed as Log $_{2}$ fold change of median fluorescence intensity (MFI) relative to VC-transduced cells. Each data point represents an independent transduction $(n=5-11)$. Results are pooled from a minimum of two independent experiments. $\alpha, P<0.01$; one-way ANOVA with Dunnett's multiple comparison test relative to $\mathrm{VC}$.

(B) Time course of serially restimulated CD8+ T cells transduced with HIF-encoding vectors. Mouse CD8+ T cells were transduced with RV-vectors $24 \mathrm{~h}$ after TCR activation. Phenotype of transduced cells was assessed by flow cytometry at days 7,14 and 21 post-transduction. Transduced cells were restimulated at days 7 and 14 post-transduction.

(C) Heatmap representing MFI or \% IFNy+ over time in transduced CD8+ T cells, as described in (B). IFNy levels were measured after stimulation with PMA and ionomycin for 4 hours. 
A

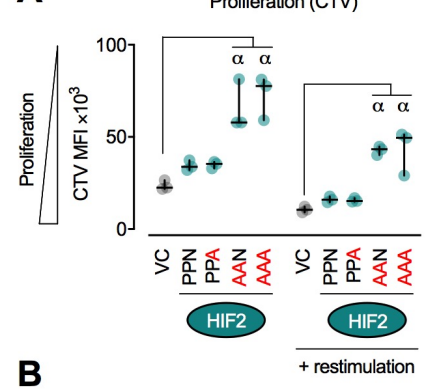

B

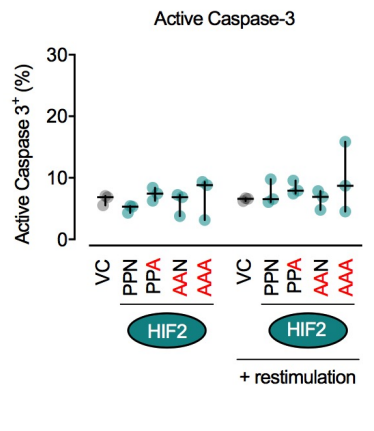

C

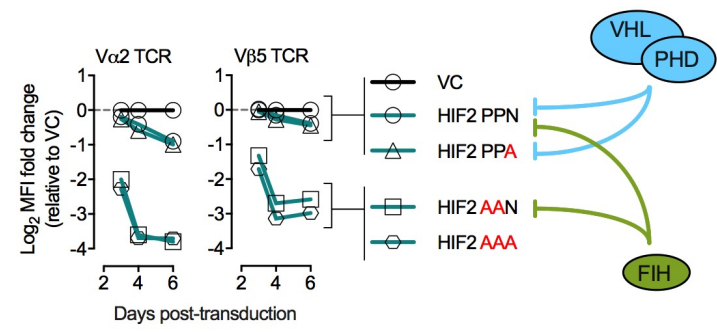

\section{Supplementary Figure 3. Ectopic expression of VHL-insensitive HIF-2a reduces CD8+ T-cell proliferation and surface TCR expression while VHL-sensitive HIF-2a increases expression of granzyme B.}

(A) CD8+ T cells were transduced with HIF-2a-coding vectors and 6 days later were loaded with the proliferation dye cell trace violet (CTV) and either restimulated with $\alpha C D 3 / C D 28$ beads or left unstimulated for 3 days. CTV levels were determined by flow cytometry after gating on live, singlet, CD8+. Thy-1.1+ events. Left: summary data showing mean fluorescence intensity (MFI). $n=3-4$ independent transductions. Lines: median and interquartile range. Right: representative histograms.

(B) As in (A) but for intracellular active Caspase-3 (marker for early apoptosis).

(C) Progressive loss of surface TCR chains over time in HIF-2a-transduced OT-I CD8+ T cells. Data are $\log _{2} \mathrm{MFI}$ fold change of TCR V $\alpha 2$ and TCR V 35 chains up to day 6 post-transduction, relative to $\mathrm{VC}$ at each time point.

$\alpha, P<0.01$; one-way ANOVA with Dunnett's multiple comparison test relative to VC. 
bioRxiv preprint doi: https://doi.org/10.1101/2020.06.18.159137; this version posted July 2, 2020. The copyright holder for this preprint (which was not certified by peer review) is the author/funder, who has granted bioRxiv a license to display the preprint in perpetuity. It is made available under aCC-BY-NC-ND 4.0 International license.

A

vc

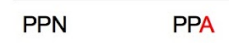

AAN

AAA

\begin{tabular}{llll}
\hline PPN & PPA & AAN
\end{tabular}
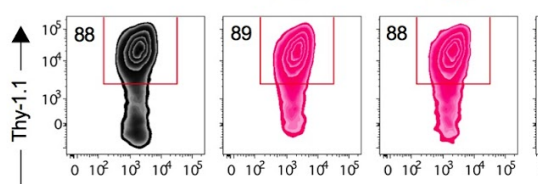

95 (@)
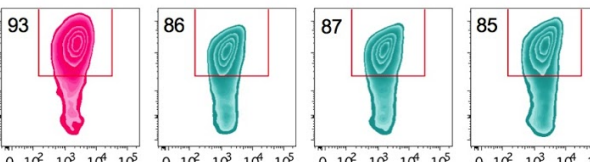

CD8

Pre-gated on live CD8+ singlets

B

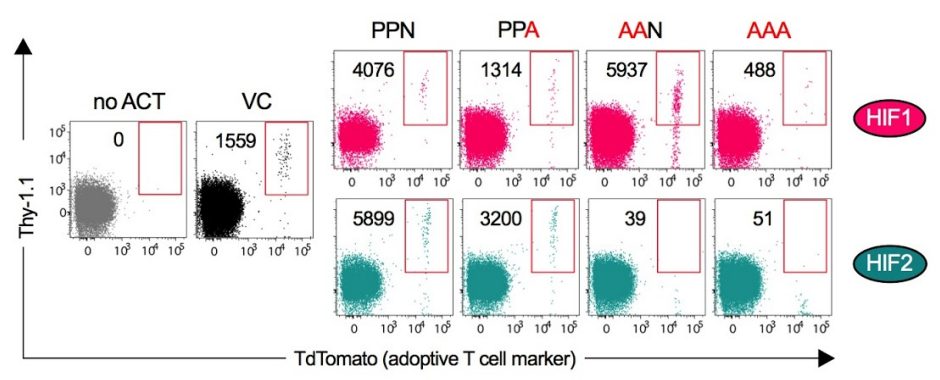

C

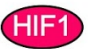

\section{HIF2}

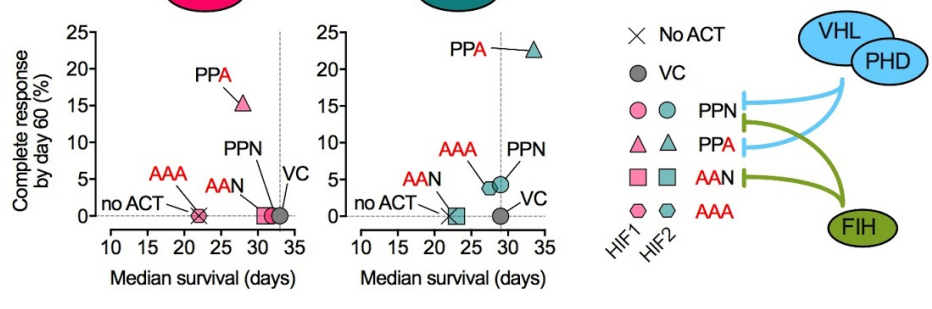

D

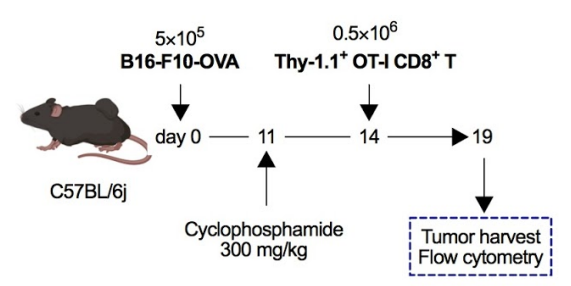

E

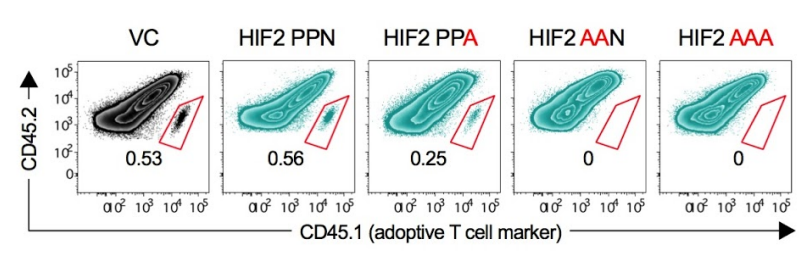

F

Tumor-infiltrating

Thy $-1.1^{+}$OT-I
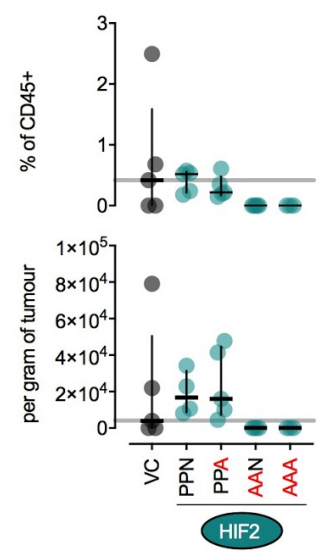

G

Tumor-infiltrating Endogenous CD8+ Tcells
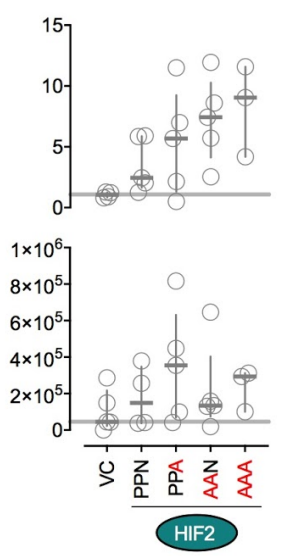
bioRxiv preprint doi: https://doi.org/10.1101/2020.06.18.159137; this version posted July 2, 2020. The copyright holder for this preprint (which was not certified by peer review) is the author/funder, who has granted bioRxiv a license to display the preprint in perpetuity. It is made available under aCC-BY-NC-ND 4.0 International license.

\section{Supplementary Figure 4. Adoptive cell transfer of HIF-1a- and HIF-2a-transduced OT-I cells into tumor-bearing mice.}

(A) $\mathrm{CD}^{+}$OT-I cells transduced with HIF-1a- and HIF-2a-coding vectors prior to adoptive cell transfer (ACT). 6 days after transduction cells were Thy-1.1 enriched using magnetic bead sorting and adoptively transferred shortly after into tumor-bearing mice.

(B) Frequency of adoptively transferred HIF-transduced OT-I cells in peripheral blood of tumor-bearing mice at day 15. Representative flow cytometry dot plots (pre-gated on CD45+ live singlets) showing TdTomato (adoptive T-cell marker) and Thy-1.1 (transduction marker). Values are events per million PBMCs within the gate. VC: vector control. No ACT: no adoptive cell therapy.

(C) Complete response rate (\% of tumor-free animals at day 60) and median survival (extrapolated from survival curves shown in Figure 8E) for groups of animals receiving ACT of VC-, HIF-1a- or HIF-2atransduced OT-I cells. Dashed lines: VC reference.

(D) Adoptive cell therapy (ACT) model. C57BL/6j mice were injected subcutaneously with $5 \times 10^{5}$ OVAexpressing B16-F10 (B16-F10-OVA) and 11 days later were lymphodepleted with $300 \mathrm{mg} / \mathrm{kg}$ cyclophosphamide. On day $14,0.5 \times 10^{6}$ HIF-2a-transduced (Thy-1.1 enriched) OVA-specific OT-I CD8+ T cells were adoptively transferred. Tumors were harvested 5 days later, dissociated into a single-cell suspension and analysed by flow cytometry.

(E) Frequency of adoptively transferred HIF-2a-transduced OT-I cells within B16-F10-OVA tumors, 5 days after ACT. Representative flow cytometry dot plots (pre-gated on CD45+ live singlets) showing CD45.1 (adoptive T-cell marker) and CD45.2 (endogenous leukocyte marker). Values are the percentage of total CD45.2 events within the gate.

(F) Frequency of tumor-infiltrating HIF-2a-transduced OT-I cells as a percentage of CD45+ cells (top)

or per gram of tumor (bottom). $n=3-5$ animals. Lines: median and interquartile range. Grey horizontal line: median for VC group.

(G) As (F) but for tumor-infiltrating endogenous CD8+ T cells.

$\alpha, P<0.01$; one-way ANOVA with Dunnett's multiple comparison test relative to VC. 
A

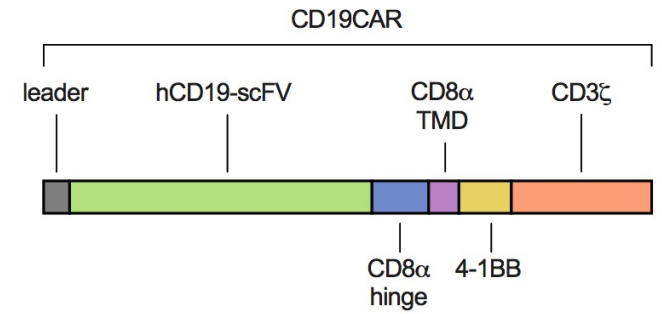

B

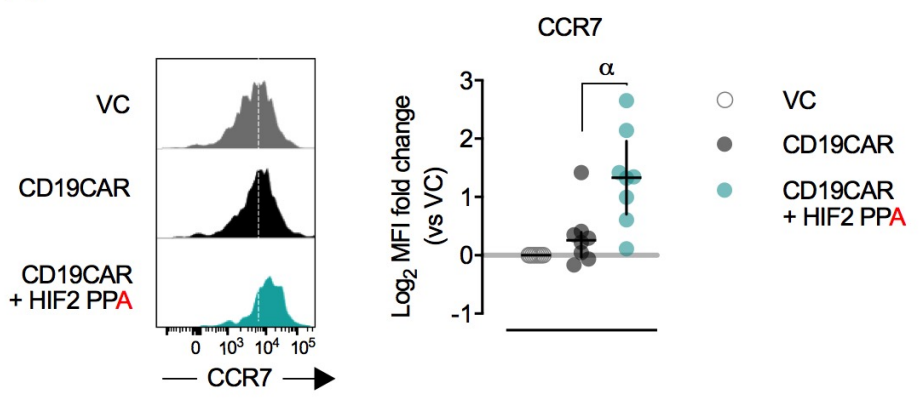

C

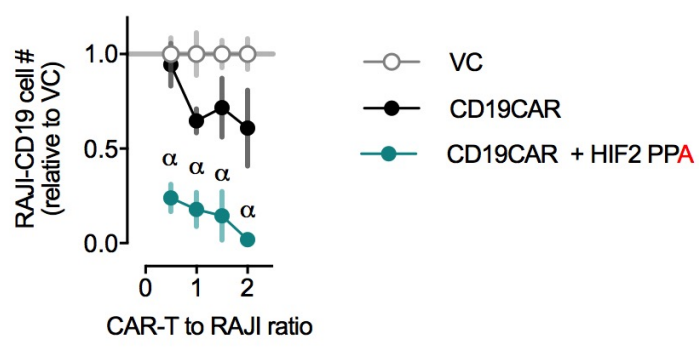

\section{Supplementary Figure 5. Ectopic expression of an anti-human CD19 CAR and FIH-insensitive HIF-2 $a$ in human CD8+ T cells.}

(A) Structure of the anti-CD19 CAR used. scFV: single-chain variable fragment. TMD: transmembrane domain. 4-1BB and $\mathrm{CD} 3 \zeta$ are the signaling domains from these proteins.

(B) Surface expression of CCR7 in transduced CD8+ T cells, pre-gated on live, singlet, CD8+, GFP+ events. Representative flow cytometry histogram and summary data of $\log _{2}$ mean fluorescence intensity (MFI) fold change versus vector control (VC). $\alpha, P<0.01$; one-way ANOVA with Dunnett's multiple comparison test relative to VC.

(C) Number of RAJI-CD19 after 20h co-culture with human CD8+ T cells transduced with VC, CD19CAR or CD19CAR and FIH-insensitive (PPA) HIF-2a at varying CAR-T to RAJI ratios. $n=5$ human donors. RAJI counts are normalized to numbers in co-culture with VC T cells at each ratio. $\alpha, P<0.01$; two-way ANOVA with Dunnett's multiple comparison test relative to VC. 
bioRxiv preprint doi: https://doi.org/10.1101/2020.06.18.159137; this version posted July 2, 2020. The copyright holder for this preprint (which was not certified by peer review) is the author/funder, who has granted bioRxiv a license to display the preprint in perpetuity. It is made available under aCC-BY-NC-ND 4.0 International license.

\title{
Protein Sequences
}

Peptide sequence for vector encoding mouse HIF-1a and mouse HIF-2a

\begin{abstract}
MNPAISVALLLSVLQVSRGQKVTSLTACLVNQNLRLDCRHENNTKDNSIQHEFSLTREKRKHVLSGTLGIPEHTY RSRVTLSNQPYIKVLTLANFTTKDEGDYFCELRVSGANPMSSNKS ISVYRDKLVKCGGISLLVQNTSWMLLLLLS LSLLQALDF ISLRAKRGSGATNFSLLKQAGDVEENPGPMEGAGGENEKKKMSSERRKEKSRDAARSRRSKESEVF YELAHQLPLPHNVSSHLDKASVMRLTISYLRVRKLLDAGGLDSEDEMKAQMDCFYLKALDGFVMVLTDDGDMVYI SDNVNKYMGLTQFELTGHSVFDFTHPCDHEEMREMLTHRNGPVRKGKELNTQRSFFLRMKCTLTSRGRTMNIKSA TWKVLHCTGH IHVYDTNSNQPQCGYKKPPMTCLVLICEP IPHPSNIEIPLDSKTFLSRHSLDMKF SYCDERITEL MGYEPEELLGRS IYEYYHALDSDHLTKTHHDMFTKGQVTTGQYRMLAKRGGYVWVETQATVIYNTKNSQPQCIVC VNYVVSGIIQHDLIFSLQQTESVLKPVESSDMKMTQLFTKVESEDTSCLFDKLKKEPDALTLLAAAAGDTIISLD FGSDDTETEDQQLEDVPLYNDVMFPSSNEKLNINLAMSPLPSSETPKPLRSSADPALNQEVALKLESSPESLGLS FTMPQIQDQPASPSDGSTRQSSPERLLQENVNTPNFSQPNSPSEYCFDVDSDMVNVFKLELVEKLFAEDTEAKNP FSTQDTDLDLEMLAAYIPMDDDFQLRSFDQLSPLESNSPSPPSMSTVTGFQQTQLQKPTITATATTTATTDESKT ETKDNKEDIKILIASPSSTQVPQETTTAKASAYSGTHSRTASPDRAGKRVIEQTDKAHPRSLNLSATLNQRNTVP EEELNPKTIASQNAQRKRKMEHDGSLFQAAGIGTLLQQPGDCAPTMSLSWKRVKGF ISSEQNGTEQKTI ILIPSD LACRLLGQSMDESGLPQLTSYDCEVAAPIQGSRNLLQGEELLRALDQVNRAKRGSGATNFSLLKQAGDVEENPGP MTADKEKKRSSSELRKEKSRDAARCRRSKETEVFYELAHELPLPHSVSSHLDKAS IMRLAISFLRTHKLLSSVCS ENESEAEADQQMDNLYLKALEGF IAVVTQDGDMIFLSENISKFMGLTQVELTGHS IFDFTHPCDHEE IRENLTLK NGSGFGKKSKDVSTERDFFMRMKCTVTNRGRTVNLKSATWKVLHCTGQVRVYNNCPPHSSLCGSKEPLLSCLIIM CEPIQHPSHMDIPLDSKTFLSRHSMDMKFTYCDDRILELIGYHPEELLGRSAYEFYHALDSENMTKSHQNLCTKG QVVSGQYRMLAKHGGYVWLETQGTVIYNPRNLQPQC IMCVNYVLSE IEKNDVVFSMDQTESLFKPHLMAMNSIFD SSDDVAVTEKSNYLFTKLKEEPEELAQLAATPGDAIISLDFGSQNFDEPSAYGKAILPPGQPWVSGLRSHSAQSE SGSLPAFTVPQADTPGNTTPSASSSSSCSTPSSPEDYYSSLENPLKIEVIEKLFAMDTEPRDPGSTQTDFSELDL ETLAAYIPMDGEDFQLSPICPEEPLMPESPQPTPQHCFSTMTS IFQPLTPGATHGPFFLDKYPQQLESRKTESEH WPMSSIFFDAGSKGSLSPCCGQASTPLSSMGGRSNTQWPPDPPLHFGPTKWPVGDQSAESLGALPVGSSQLEPPS APPHVSMFKMRSAKDFGARGPYMMSPAMIALSNKLKLKRQLEYEEQAFQDTSGGDPPGTSSSHLMWKRMKSLMGG TCPLMPDKTISANMAPDEFTQKSMRGLGQPLRHLPPPQPPSTRSSGENAKTGFPPQCYASQFQDYGPPGAQKVSG VASRLLGPSFEPYLLPELTRYDCEVAVPVPGSSTLLQGRDLLRALDQAT
\end{abstract}

Key:

\begin{tabular}{|l|l|}
\hline Protein Name & NCBI Reference Sequence \\
\hline Thy-1.1 & AAR17087.1 \\
\hline Furin Cleavage site & RAKR (Cleavage after R) \\
\hline $\begin{array}{l}\text { Picornavirus 2A self-cleaving } \\
\text { sequence }\end{array}$ & $\begin{array}{l}\text { GSGATNFSLLKQAGDVEENPGP } \\
\text { (Cleavage ocCurs between G and P) }\end{array}$ \\
\hline Mouse HIF-1 $\alpha$ & NP_034561.2 \\
\hline Mouse HIF-2 $\alpha$ & NP_034267.3 \\
\hline $\begin{array}{l}\text { A Proline residue converted to } \\
\text { Alanine }\end{array}$ & \\
\hline $\begin{array}{l}\text { A Asparagine residue converted to } \\
\text { Alanine }\end{array}$ & \\
\hline
\end{tabular}


bioRxiv preprint doi: https://doi.org/10.1101/2020.06.18.159137; this version posted July 2, 2020. The copyright holder for this preprint (which was not certified by peer review) is the author/funder, who has granted bioRxiv a license to display the preprint in perpetuity. It is made available under aCC-BY-NC-ND 4.0 International license.

\section{Peptide sequence for vector encoding chicken ovalbumin (OVA)}

MGSIGAASMEFCFDVFKELKVHHANENIFYCPIAIMSALAMVYLGAKDSTRTQINKVVRFDKLPGFGDSIEAQCG TSVNVHSSLRDILNQITKPNDVYSFSLASRLYAEERYP ILPEYLQCVKELYRGGLEP INFQTAADQARELINSWV ESQTNGI IRNVLQPSSVDSQTAMVLVNAIVFKGLWEKAFKDEDTQAMPFRVTEQESKPVQMMYQIGLFRVASMAS EKMK ILELPFASGTMSMLVLLPDEVSGLEQLESI INFEKLTEWTSSNVMEERKI KVYLPRMKMEEKYNLTSVLMA MGITDVFSSSANLSGISSAESLKISQAVHAAHAEINEAGREVVGSAEAGVDAASVSEEFRADHPFLFCIKH IATN AVLFFGRCVSPGSGATNFSLLKQAGDVEENPGPMVSKGEELFTGVVPILVELDGDVNGHKF SVSGEGEGDATYGK LTLKF ICTTGKLPVPWPTLVTTLTYGVQCFSRYPDHMKQHDFFKSAMPEGYVQERTIFFKDDGNYKTRAEVKFEG DTLVNRIELKGIDFKEDGNILGHKLEYNYNSHNVY IMADKQKNGIKVNFKIRHNIEDGSVQLADHYQQNTP IGDG PVLLPDNHYLSTQSALSKDPNEKRDHMVLLEFVTAAGITLGMDELYKGSGEGRGSLLTCGDVEENPGPMIEQDGL HAGSPAAWVERLFGYDWAQQTIGCSDAAVFRLSAQGRPVLFVKTDLSGALNELQDEAARLSWLATTGVPCAAVLD VVTEAGRDWLLLGEVPGQDLLSSHLAPAEKVS IMADAMRRLHTLDPATCPFDHQAKHRIERARTRMEAGLVDQDD LDEEHQGLAPAELFARLKARMPDGEDLVVTHGDACLPNIMVENGRF SGF IDCGRLGVADRYQDIALATRDIAEEL GGEWADRFLVLYGIAAPDSQRIAFYRLLDEFF

\begin{tabular}{|l|l|}
\hline Protein Name & NCBI Reference Sequence \\
\hline Chicken ovalbumin & $\begin{array}{l}\text { AUD54526.1 H2K-b-restricted OVA } \\
\text { peptide (SIINEKL) marked in bold. }\end{array}$ \\
\hline $\begin{array}{l}\text { Picornavirus 2A self-cleaving } \\
\text { sequence }\end{array}$ & $\begin{array}{l}\text { GSGATNFSLLKQAGDVEENPGP } \\
\text { (Cleavage occurs between G and P) }\end{array}$ \\
\hline eGFP & ADQ43426.1 \\
\hline Neomycin phosphotransferase & CAD21956.1 \\
\hline
\end{tabular}


bioRxiv preprint doi: https://doi.org/10.1101/2020.06.18.159137; this version posted July 2, 2020. The copyright holder for this preprint (which was not certified by peer review) is the author/funder, who has granted bioRxiv a license to display the preprint in perpetuity. It is made available under aCC-BY-NC-ND 4.0 International license.

Peptide sequence for vector encoding CAR and human HIF-2a

\begin{abstract}
MVSKGEELFTGVVP ILVELDGDVNGHKFSVSGEGEGDATYGKLTLKF ICTTGKLPVPWPTLVTTLTYGVQCF SRY PDHMKQHDFFKSAMPEGYVQERTIFFKDDGNYKTRAEVKFEGDTLVNRIELKGIDFKEDGNILGHKLEYNYNSHN VYIMADKQKNGIKVNFKIRHNIEDGSVQLADHYQQNTP IGDGPVLLPDNHYLSTQSALSKDPNEKRDHMVLLEFV TAAGITLGMDELYKRAKRGSGSGATNFSLLKQAGDVEENPGPMALPVTALLLPLALLLHAARPDIQMTQTTSSLS ASLGDRVTISCRASQDISKYLNWYQQKPDGTVKLLIYHTSRLHSGVPSRFSGSGSGTDYSLTISNLEQEDIATYF CQQGNTLPYTFGGGTKLEITGGGGSGGGGSGGGGSEVKLQESGPGLVAPSQSLSVTCTVSGVSLPDYGVSWIRQP PRKGLEWLGVIWGSETTYYNSALKSRLTIIKDNSKSQVFLKMNSLQTDDTAIYYCAKHYYYGGSYAMDYWGQGTS VTVSSTTTPAPRPPTPAPTIASQPLSLRPEACRPAAGGAVHTRGLDFACDIYIWAPLAGTCGVLLLSLVITLYCK RGRKKLLYIFKQPFMRPVQTTQEEDGCSCRFPEEEEGGCELRVKFSRSADAPAYKQGQNQLYNELNLGRREEYDV LDKRRGRDPEMGGKPRRKNPQEGLYNELQKDKMAEAYSE IGMKGERRRGKGHDGLYQGLSTATKDTYDALHMOAL PPRRAKRRSGSGATNFSLLKQAGDVEENPGPMTADKEKKRSSSERRKEKSRDAARCRRSKETEVFYELAHELPLP HSVSSHLDKAS IMRLAISFLRTHKLLSSVCSENESEAEADQQMDNLYLKALEGFIAVVTQDGDMIFLSENISKFM GLTQVELTGHSIFDFTHPCDHEE IRENLSLKNGSGFGKKSKDMSTERDF FMRMKCTVTNRGRTVNLKSATWKVLH CTGQVKVYNNCPPHNSLCGYKEPLLSCLI IMCEP IQHPSHMDIPLDSKTFLSRHSMDMKFTYCDDRITELIGYHP EELLGRSAYEFYHALDSENMTKSHQNLCTKGQVVSGQYRMLAKHGGYVWLETQGTVIYNPRNLQPQCIMCVNYVL SEIEKNDVVF SMDQTESLFKPHLMAMNS IFDSSGKGAVSEKSNFLFTKLKEEPEELAQLAPTPGDAI ISLDFGNQ NFEESSAYGKAILPPSQPWATELRSHSTQSEAGSLPAFTVPQAAAPGSTTPSATSSSSSCSTPNSPEDYYTSLDN DLKIEVIEKLFAMDTEAKDQCSTQTDFNELDLETLAPY IPMDGEDFQLSP ICPEERLLAENPQSTPQHCFSAMTN IFQPLAPVAPHSPFLLDKFQQQLESKKTEPEHRPMSS IFFDAGSKASLPPCCGQASTPLSSMGGRSNTQWPPDPP LHFGPTKWAVGDQRTEFLGAAPLGPPVSPPHVSTFKTRSAKGFGARGPDVLSPAMVALSNKLKLKRQLEYEEQAF QDLSGGDPPGGSTSHLMWKRMKNLRGGSCPLMPDKPLSANVPNDKFTQNPMRGLGHPLRHLPLPQPPSAISPGEN SKSRFPPQCYATQYQDYSLSSAHKVSGMASRLLGPSFESYLLPELTRYDCEVAVPVLGSSTLLQGGDLLRALDQA $\mathrm{T}$
\end{abstract}

\begin{tabular}{|c|c|c|}
\hline \multicolumn{2}{|c|}{ Protein Name } & NCBI Reference Sequence \\
\hline \multicolumn{2}{|l|}{ eGFP } & $\underline{\mathrm{ADQ} 43426.1}$ \\
\hline \multicolumn{2}{|c|}{ Furin cleavage site } & RAKR (cleavage after $\mathbf{R}$ ) \\
\hline \multicolumn{2}{|c|}{ Picornavirus $2 \mathrm{~A}$ self-cleaving sequence } & $\begin{array}{l}\text { GSGATNFSLLKQAGDVEENPGP } \\
\text { (cleavage occurs between } \mathbf{G} \\
\text { and } \mathbf{P} \text { ) }\end{array}$ \\
\hline \multirow[t]{6}{*}{ hCD19 CAR } & CD8a signal peptide & NP 001139345.1 \\
\hline & hCD19-SCFv & \\
\hline & CD8a hinge & NP 001139345.1 \\
\hline & CD8a TMD & NP 001139345.1 \\
\hline & $4-1 \mathrm{BB}$ & NP 001552.2 \\
\hline & $\mathrm{CD} 3 \mathrm{z}$ & NP 000725.1 \\
\hline \multicolumn{2}{|c|}{ Human $H I F-2 \alpha$} & NP 001421.2 \\
\hline \multicolumn{2}{|c|}{ A Asparagine residue converted to Alanine } & N847A \\
\hline
\end{tabular}


bioRxiv preprint doi: https://doi.org/10.1101/2020.06.18.159137; this version posted July 2, 2020. The copyright holder for this preprint (which was not certified by peer review) is the author/funder, who has granted bioRxiv a license to display the preprint in perpetuity. It is made available under aCC-BY-NC-ND 4.0 International license.

Modified HIF expression in CD8+ T cells increases anti-tumor efficacy

Veliça et al. 